\title{
ESTADO, SOCIEDADE E MERCADO. INTERAÇÕES E REFLEXOS SOCIAIS.
}

\author{
Elizabeth Guimarães Machado*
}

\begin{abstract}
SUMÁRIO: Introdução. 1. Contornos dos reflexos sociais decorrentes da atividade empresarial em ambiente globalizado. 2. Os paradigmas do Estado de Direito e do Estado do Bem-estar social ante a iniciativa privada. 3. O exercício da atividade empresária no Estado Democrático de Direito aliado à prática da responsabilidade social corporativa. 4. Transição da democracia representativa para a democracia participativa. 5. O papel do Estado na promoção do bem-estar social. Conclusão. Bibliografia.
\end{abstract}

RESUMO: A ética social é um atributo indispensável para organizações que querem manter-se vivas no mercado, e a sociedade civil está cada vez mais alerta para os desvios de conduta das organizações e suas conseqüências, além da busca de uma igualdade social. A racionalidade do sistema econômico capitalista não se vê voltada, especificamente, para atender ao consumidor em suas necessidades sociais, ou mesmo da sociedade civil em seu entorno. Estimula o consumismo num mercado global, ante a idéia de que, através de um consumo cada vez maior, o crescimento econômico ocorrerá, gerando oportunidades de renda e circulação de riquezas. As necessidades sociais, constantemente, não são levadas em consideração pelos empresários que buscam uma lucratividade maior em suas atividades, sob a alegação de que a principal responsabilidade das empresas é maximizar o lucro dos investidores, cabendo ao Estado a preocupação com o social. Verifica-se, por sua vez, a necessidade do intervencionismo estatal na economia, refletida pela atuação do Estado no sentido de adoção de medidas protecionistas em favor da comunidade civil, com motivação de ordem social como: busca de igualdade na distribuição dos recursos e de poder na sociedade civil, e a busca pelo ideal democrático, visando à participação dos cidadãos neste processo.

Palavras-chave: Empresa. Mercado. Função social. Responsabilidade social.

ABSTRACT: Social ethic is an indispensable predicate for an organization which intends to keep itself in the market place and civil society is increasingly alert for the deviation of conduct and its consequences by companies, besides the civil society's growing search for social equality. Besides, according to economist Milton Friedman, the reason for capitalism to exist is not the consumers' social needs, neither the society where they are found. Capitalism stimulates consumerism in a global market, selling the idea that greater consumption of goods leads to economical growth, generating jobs and wealth circulation. Social needs often are not taken into consideration by executives, who only seek greater profits in their activities, claiming that their major duty is to maximize investors' profits. The social issues, in their view, should be taken care by the government. It is verified, therefore, the need of State intervention in the market, by adopting preservative measures in favor of the civil community, measures that will be based on the society's best interest such as: search for equality in the distribution of resources and power in the civil society; search for the democratic ideal, having all citizens participate in the decisions which will affect all. Keywords: Organization. Company. Market. Social function. Social responsibility.

\section{INTRODUÇÃO}

A recente passagem de século instigou pessoas do mundo inteiro à reflexão sobre as atuais condições de vida planetária e as perspectivas de futuro

\footnotetext{
* Doutorado em andamento em Direito - Discipl. Isolada - Teoria da Empresa . Mestrado em Direito Empresarial pela UIT (2006). Especializações: (1) em Gerência de Empresas pela FACCO (1996) e (2) em Direito Empresarial pela FADOM (1997). Graduação em Direito pela Faculdade de Direito Milton Campos (1985).
}

Revista de Estudos Jurídicos, a. 15, n. 22, 2011 
da humanidade, realçando o que já vinha sendo alertado principalmente a partir dos anos 90, sobre a precariedade e a crescente deterioração das condições de vida social e econômica para a grande massa popular mundial e, principalmente, os danos ao meio ambiente, a nível global, contrastando com o crescente poder decorrente da atividade empresarial, inserida neste ambiente e suas afetações com governos, sociedade civil e meio ambiente.

Em decorrência do desenvolvimento da tecnologia e do conseqüente avanço dos meios de comunicação em massa, aflorou, nas pessoas, o despertar de uma consciência eticamente mais crítica e reforça o desconforto ante a indiferença e o sentimento de impotência no mero espectador, frente a relações de poder não igualitárias, não inclusivas, daí gerando reflexos de gradativa e crescente alteração de posturas, de meros espectadores, a atores sociais responsáveis, com propostas de reformulações das relações sociais e respectivos paradigmas de valor, num estado democrático de direito, em persecução do desenvolvimento sustentável global.

Este trabalho tem como proposta o estudo sobre a postura do Estado em suas diversas formatações e demais atores ante o agravamento das necessidades sociais e de danos ambientais contrastados com a meta principal da atividade empresarial focada na lucratividade, além de crescente poderio e influência das empresas na vida social e no meio ambiente, aliado à tendência de delegação ao governo das atribuições quanto ao bem-estar social, e as novas posturas sociais corporativas em busca de um desenvolvimento sustentável, com fortalecimento da imagem e alcance de mercado a longo prazo.

Utilizando a metodologia de pesquisa em bases bibliográficas, procuramos uma maior abrangência, quanto à busca, de entendimentos doutrinários sobre o tema.

Abordamos o direito positivo, além da base doutrinária, para distinguirmos a atividade empresarial da não empresarial, ambas de fundamento econômico, em conformidade com o Código Civil em vigor.

Prosseguimos nosso estudo com a análise dos paradigmas e a evolução do Estado de Direito ao Estado do Bem-estar Social e, finalmente, ao Estado Democrático de Direito, este último adotado como nosso marco teórico.

Estudamos a aparente transição da democracia representativa para a participativa, na visão de que esta última, ainda em fase embrionária, constitui mola propulsora para a responsabilidade social corporativa. Analisamos o papel do Estado na promoção do bem-estar social, nos setores da sociedade e na crescente parceria intersetorial como um dos enfoques do fundamento do papel do Estado "versus" o papel das empresas no contexto social e as respectivas responsabilidades, sob a ótica do desenvolvimento sustentável.

\section{CONTORNOS DOS REFLEXOS SOCIAIS DECORRENTES DA ATIVIDADE EMPRESARIAL EM AMBIENTE GLOBALIZADO.}

As empresas, assim consideradas pelo exercício efetivo de atividade empresarial, no âmbito individual ou coletivo, têm grande impacto nas atividades 
humanas. Na atualidade, é inconcebível a vida em sociedade sem a dependência do resultado da atuação das empresas. Alfredo Lamy Filho ${ }^{1}$ descreve o vínculo crescente da empresa na vida do homem moderno, vínculo este ligado ao progresso econômico e à conquista do bem-estar social, fenômeno tendente a um "crescimento em marcha acelerada, e não revela indícios de reversão". Vista por sua importância econômica, é considerada uma "unidade de produção da economia moderna", aliada à importância social traduzida pelo significado humano por representar um "quadro de encontro dos homens para a ação em comum que lhes assegura sua existência". Na fala do autor, dependemos da empresa:

para o nosso trabalho, e nosso lazer, para nos transportarmos e nos comunicarmos, para a produção de alimentos ou de mobiliário e vestuário, para a defesa de nossa saúde, para a habitação, para a produção de toda essa parafernália de utilidades empregadas no diaa-dia do homem moderno. [...] Não é por outro motivo que, em toda a parte, os estudiosos das ciências políticas, sociais e econômicas se voltaram para a análise da empresa, a 'célula de base de toda a economia moderna', o grande instrumento de criação de riquezas, de poder e de promoção individual, e, ao mesmo tempo, origem e solução dos problemas, de complexidade crescente que fazem a grandeza e a miséria da vida do homem moderno.

O cerne da atividade empresarial é a busca da lucratividade e do crescimento econômico, aliado à necessidade de sua sustentabilidade no mercado, situação "sine qua non" para viabilizar a perpetuidade do exercício desta atividade, o que nos leva ao entendimento de sua dependência ligada a estratégias administrativas que visam ao desenvolvimento sustentável destas empresas, inseridas num contexto global ${ }^{2}$.

${ }^{1}$ LAMY FILHO, Alfredo. A empresa - formação e evolução - responsabilidade social. In Novos estudos de direito comercial em homenagem a Celso Barbi Filho. SANTOS, Theophilo de Azeredo (Coordenador). Rio de Janeiro: Forense, 2003, p. 1-2.

2 Alfredo Lamy Filho mostra em seu artigo sobre a formação e evolução da empresa - responsabilidade social, citado supra, p. 2-3, a dependência que o homem moderno advinda do resultado da atividade empresarial, sendo esta o meio através do qual é promovido o desenvolvimento social, econômico, científico, tecnológico e industrial que, segundo Francis-Paul Benoit, referenciado pelo autor, "implicam a evolução do saber, dos meios e das mentalidades. Com a revolução tecnológica que vivemos, o homem criou utilidades novas; essas utilidades mudam as condições de vida, e podem mudar o próprio homem. São as empresas que, fundamentalmente, têm feito face aos difíceis problemas de iniciativa, do controle - e da aceitação também - dessas transformações." Acrescenta os comentários dos empresários François Dalle e J. Bounine inseridos no livro Quand l'Entreprise s'Éveille à la Conscience Sociale (Paris, 1975), assim transcritos: "no curso dos últimos anos, as sociedades industriais viram crescer seus índices de produção a taxas jamais igualadas. Seus membros puderam beneficiar-se de uma abundância de bens materiais e modos de vida que teriam sido inimagináveis há apenas quinze anos [o livro foi publicado em 1975]. Mas, para tanto, tiveram que consentir em viver em estado de simbiose sem precedentes com a empresa. Jamais os homens, em atividade ou aposentados, trabalhando ou viajando, repousando ou se alimentando, sentiram tão intensamente como em nossos dias os efeitos do processo de industrialização." 
O fenômeno da globalização, traduzido pelo funcionamento do mercado atual que "impõe uma integração econômica que favorece aos países ricos"3, "ipso facto", apresenta uma falha estrutural, posto que mostra sua incapacidade de satisfazer a grupos de pessoas que se encontram na condição de excluídas, cuja magnitude é variável ${ }^{4}$. Como nos mostra Zygmunt Bauman em seu livro "Globalização: as conseqüências humanas" 5 , essa falha produz riqueza e bens, através da atividade empresarial, produzindo o efeito de aumentar o círculo de dependentes das novas necessidades que cria, sendo que, grande parte da população não pode gozar desta riqueza e bens, devido à precariedade de recursos e ao aumento do fosso entre ricos e pobres ${ }^{6}$, cuja distância social é fator que gera instabilidade não só social, mas também na preservação da atividade empresarial, que tem seu mercado consumidor reduzido, pela privação do cidadão comum ao acesso ao consumo, ou seja, o ciclo produtivo torna-se insustentável com a redução do mercado consumidor, cada vez com menor poder aquisitivo.

Alfredo Lamy Filho ${ }^{7}$ faz referência à ascensão da empresa moderna que ultrapassa os limites do simples exercício da atividade para o mercado, adquirindo um "status" de grande significado econômico, político e social, efeitos estes que se projetam em termos de poder. Neste sentido, ensina:

Com efeito, cada empresa representa um universo, integrado pelos recursos financeiros de que dispõe e pelo número de pessoas que mobiliza a seu serviço direto. $\mathrm{O}$ círculo de dependentes das decisões empresariais não se esgota aí, no entanto. Assim, no campo econômico-financeiro a atividade traz repercussões aos fornecedores dos insumos, às empresas concorrentes ou complementares, aos consumidores que se habituaram aos seus produtos, aos investidores

3 FARIAS, Edilsom. Democracia, censura e liberdade de expressão e informação na Constituição Federal de 1988 . Jus Navigandi, Teresina, a. 5, n. 51, out. 2001. Disponível em: $<$ http://jus2.uol.com.br/doutrina/texto.asp?id=2195>. Acesso em: 5 fev. 2006.

4 Ver. LORENZETTI, Ricardo Luis. Consumidores. Buenos Aires: Rubinzal - Culzoni Editores, 2003.

5 BAUMAN, Zygmunt. Globalização: as conseqüências humanas. Tradução de Marcus Penchel. Rio de Janeiro: Jorge Zahar Editor, 1999. O livro contém importante estudo sobre as consequiências da globalização em nossos tempos, com dados estatísticos e referências a diversos autores, tais como: John Kavanagh, do Instituto de Pesquisa Política de Washington; Ryszard Kapuscinski, cronista do The Economist, mostrando casos vivenciados pelo cronista na África e dados estatísticos que comprovam o problema da pobreza mundial, editado sob o título "Como alimentar o mundo", além de, entre outros, Jeremy Seabrook, Lester Thurow e Robert Reich; Martin Woollacott; Georg Henrik von Wright. Um referencial para quem quer aprofundar pesquisa sobre o tema.

6 Bernardo Kliksberg fez um importante estudo sobre este tema, referenciado pelo autor como uma "falha do mercado" e as diferenças por ela criadas, com mostras de dados estatísticos relacionados aos problemas sociais da América Latina, publicado em seu livro: Falácias e mitos do desenvolvimento social. Tradução de Sandra Trabucco Valenzuela, Silvana Cobucci Leite. São Paulo: Cortez. Brasília, DF: UNESCO, 2001. Outro autor que analisa e critica o capitalismo mostrando suas contradições e diferenças criadas em decorrência deste sistema, é o filósofo húngaro István Mészáros, em monumental obra intitulada Para além do capital - rumo a uma teoria da transição. Traduzido por Paulo César Castanheira e Sérgio Lessa. São Paulo: Boitempo Editorial, 2002. No Brasil, ver FISCHER, Rosa Maria. O desafio da colaboração: práticas de responsabilidade social entre empresas e terceiro setor. São Paulo: Editora Gente, 2002, p.33.

7 LAMY FILHO, Alfredo. A empresa... op. cit. p. 14-15. 
que se associaram à empresa, e aos mercados em geral; no setor humano, a empresa, como se disse, é campo de promoção e realização individual, cuja ação (de propiciar emprego, demitir, promover, remover, estimular e punir) ultrapassa a pessoa diretamente atingida para projetar-se nos campos familiar e social.

Os efeitos da atividade empresarial, no meio social, sugerem uma administração empresarial visando a mudanças, por meio de melhores alternativas em termos econômicos, sociais, ecológicos e humanos, com a utilização de estratégias que levem a um resultado que atenda aos interesses empresariais, que não podem perder o foco no mercado consumidor. Este, por sua vez, tem sido afetado pela desigualdade social, gerada pelo empobrecimento da grande maioria da população global, aliado à perda da qualidade de vida pessoal, social e ao crescente esgotamento dos recursos naturais e efeitos negativos, que a atividade empresarial tem gerado ao ecossistema, como muito bem relata Bernardo Kliksberg ${ }^{8}$ quando confronta as realidades da América Latina relacionadas à pobreza, desigualdade e deterioração da família:

[...] as extremas desigualdades no acesso a oportunidades socioeconômicas mantêm e intensificam dramas como a miséria em que vivem as comunidades indígenas, a marginalização da população de cor em alguns países, a subordinação da mulher, particularmente da mulher pobre, em diversas áreas, a isso, surge uma sociedade com grandes fraturas, que geram exclusão, tensão social e com freqüência, ideologias intolerantes que visam justificar tais fraturas.

Barrington Moore, Jr. ${ }^{9}$, estudando os aspectos morais do crescimento econômico, nos mostra como o mercado gera desigualdades, com a conseqüente perda do poder aquisitivo do cidadão comum, efeito este que resultará num risco de redução de clientela do empresário, gerado pela falta de poder aquisitivo dos afetados:

[...] o mercado reproduz fielmente todas as injustiças da sociedade vigente. Mais do que isso, parece que, numa sociedade de mercado, o rico fica cada vez mais rico e o pobre cada vez mais pobre. Vantagens geram mais vantagens de um dos lados na relação de troca, e o contrário é também verdadeiro.

Neste contexto, algumas empresas têm direcionado suas atividades para objetivos concretos, no sentido de gerar um desenvolvimento sustentável, buscando não só a execução de metas, com vistas à lucratividade por meio de

8 KLIKSBERG, Bernardo. Falácias e mitos do desenvolvimento social. Tradução de Sandra Trabucco Valenzuela, Silvana Cobucci Leite. São Paulo: Cortez; Brasília, DF: UNESCO, 2001, p. 47.

9 MOORE, Barrington Jr. Aspectos morais do crescimento econômico e outros ensaios. Tradução Max Altman. Rio de Janeiro: Record, 1999, p. 172. [Título original norte-americano: Moral aspects of economics growth and other essays]. 
arranjos produtivos, mas também tentando proporcionar sua continuidade, tendo, para isto, que minimizar os efeitos deletérios que vêm afetando a sociedade global e o meio ambiente, gerando a preocupação paralela com a sociedade civil em seu entorno.

Nos últimos anos muito se tem avançado neste sentido, entretanto há um longo caminho a ser percorrido, conforme aponta Bernardo Kliksberg ${ }^{10}$, citando a América Latina:

Demonstrou-se que o social não se resolve através do 'derrame'. Na maioria dos casos estudados pelos informes sobre Desenvolvimento Humano da Organização das Nações Unidas, por exemplo, mesmo havendo crescimento econômico, em condições de alta desigualdade, ele não circula, tende a estacionar-se em certos setores da sociedade. Os perdedores continuam aumentando e os ganhadores aumentam suas brechas relativas com respeito a eles.

Por outro lado, independentemente da iniciativa de buscar o desenvolvimento sustentável de suas atividades e a promoção do bem-estar social em seu redor, as empresas, que, se por meio de suas atividades, contribuem para a ocorrência de dano social ou ecológico, devem ter a responsabilidade de prevenir sua não-ocorrência, ou saná-los, caso já provocados. Neste sentido, leciona Alfredo Lamy Filho ${ }^{11}$ ao mostrar os efeitos abrangentes e significativos que as decisões das pequenas, médias e, principalmente, das grandes empresas, que têm o condão de afetar a vida econômica, política e social da sociedade em geral, mostrando o poder que detêm ${ }^{12}$. Segundo o autor, as decisões empresariais

10 KLIKSBERG, Bernardo. Falácias... op. cit . p. 99

11 LAMY FILHO, Alfredo. A empresa... op. cit. p. 15.

12 István Mészáros, em sua obra Para além do capital... op. cit. p. 1085-1086 alerta sobre o antagonismo político resultante da penetração econômica dos EUA em proporção global e tendência do empresário internacional em sua persecução ao lucro, cujos dados extraídos de: The Guardian, 5 de fevereiro de 1986. Selling off, and shrugging yet again e comentários do autor transcrevemos: "Em meio a um recente escândalo político, que se seguiu à revelação de negociações secretas do governo com empresas gigantescas dos EUA, o líder do Partido Trabalhista britânico referia-se a 'mais um ato de colonização na economia britânica.' Ele conseguiu pleno apoio da imprensa liberal. Um editorial do The Guardian protestava: Inicialmente foi a United Technologies, negociando para controlar a Westland (e sendo bemsucedida com o auxílio da manipulação governamental e de transações suspeitas sob o manto do sigilo). Em seguida a General Motors com a Lotus; depois a ameaça de retirar o radar aerotransportado da GEC (que também se tornou depois um fato consumado) e transferi-lo para as mãos da Boeing. Agora a Ford pode comprar a BL, tudo o que resta da indústria automotiva de propriedade britânica. Uma ou duas dessas negociações talvez pudessem ser desculpáveis. Mas tantas, e tão próximas umas das outras, deixam a impressão de que a Sra. Thatcher tem tão pouca fé nos fabricantes do Reino Unido, que deseja converter o país num sorvedor terceiro-mundista de produtos multinacionais.

(...) "O Sr. Bob Lutz, presidente da Ford européia, afirmou recentemente ao Financial Times: Se acharmos que temos instalações de montagem importantes, mas que, independentemente do país em questão, por uma razão ou por outra - talvez por ações governamentais impróprias (feriados mais longos, semanas de trabalho mais curtas), ou por intransigência sindical - não podem ser competitivas, não nos recusaremos a tomar a decisão de fechá-las". 
[...] de que dependem a vida e a realização de tantas pessoas e o desenvolvimento econômico em geral, são tomadas pelos administradores da empresa - que exercem, assim, um poder da mais relevante expressão, não só econômica como política e social, e o das mais fundas conseqüências na vida moderna.

O Código Civil Brasileiro vigente, adotando o princípio da socialidade, prevê a responsabilidade do empresário, individual ou coletivo, mesmo que, por atos praticados por seus prepostos, em decorrência do exercício da atividade empresarial ${ }^{13}$; disciplina ainda a responsabilidade pessoal dos prepostos por danos causados no exercício de suas atividades, devendo responder perante o preponente pelos atos culposos e, perante terceiros, solidariamente, com o preponente, pelos atos dolosos, vinculando, assim, preponente e preposto perante terceiros, sociedade e meio-ambiente ${ }^{14}$.

Por sua vez, a atividade empresarial, intrinsecamente, não representa ato ilegal ou fraudulento. Tem suas características próprias, cujo escopo é a finalidade lucrativa. Seus efeitos, nos meios econômico, social e ambiental, estes, sim, é que causam danos à vida em sociedade e ao ecossistema e devem ser prevenidos ou reparados, segundo a participação de cada ator social, individualmente, e em seu inter-relacionamento.

\section{OS PARADIGMAS DO ESTADO DE DIREITO E DO ESTADO DO BEM-ESTAR SOCIAL ANTE A INICIATIVA PRIVADA.}

O Estado de Direito é uma forma de organização política, tendo como base a separação dos poderes do legislativo, executivo e judiciário, interdependentes entre si, além da instituição de direitos fundamentais de caráter individual instituídos na Carta Magna. Conforme Marcelo Cattoni ${ }^{15}$

O paradigma liberal pressupõe uma sociedade econômica de mercado que se institucionaliza por meio do Direito Privado; vincula-se à expectativa de que se possa alcançar justiça social pela garantia de um status negativo, pela delimitação de esferas de liberdades individuais. O paradigma do Estado Social desenvolveu-

\footnotetext{
${ }^{13}$ Artigo 1.178, caput, Código Civil/2002: “Os preponentes são responsáveis pelos atos praticados por quaisquer prepostos, praticados nos seus estabelecimentos e relativos à atividade da empresa, ainda que não autorizados por escrito".

Parágrafo único do artigo 1.178, Código Civil/2002: "Quando tais atos forem praticados fora do estabelecimento, somente obrigarão o preponente nos limites dos poderes conferidos por escrito, cujo instrumento pode ser suprido pela certidão ou cópia autêntica do seu teor".

${ }^{14}$ Parágrafo único do artigo 1.177, Código Civil/2002: "No exercício de suas funções, os prepostos são pessoalmente responsáveis, perante os preponentes, pelos atos culposos; e, perante terceiros, solidariamente com o preponente, pelos atos dolosos".

${ }^{15}$ CATTONI DE OLIVEIRA, Marcelo Andrade. Coesão interna entre estado de direito e democracia na teoria discursiva do direito de Jürgen Habermas. In Jurisdição e hermenêutica constitucional no estado democrático de direito. Coordenação CATTONI DE OLIVEIRA, Marcelo Andrade. Belo Horizonte: Mandamentos, 2004, 183-184.
} 
se a partir de uma crítica consistente a essa suposição. Se a 'liberdade de poder ter e poder adquirir' deve garantir justiça social, é preciso haver uma igualdade do poder juridicamente.

Segundo preleciona Pellegrini ${ }^{16}$ no paradigma do Estado de Direito "nota-se a divisão da sociedade em duas grandes esferas": a sociedade civil, representando a esfera privada, e a sociedade política, representando a esfera pública, com o mínimo de intervenção do Estado Liberal na esfera privada, cujos parâmetros de liberdade de atuação dos atores, nesta esfera, "poderiam ser compreendidos como toda atuação que não fosse contrária ao direito, ou seja, o que não é proibido por lei é permitido". ${ }^{17}$

Com o efeito da sociedade capitalista, ante a globalização das atividades produtivas, resultando no empobrecimento da grande massa da sociedade civil, percebe-se, neste contexto, significativa exclusão social, contrastando-se com o enriquecimento e poder nas mãos de poucos, grupos estes que, em virtude de sua situação privilegiada, assumem o controle inclusive das tendências legislativas que deveriam ser de caráter genérico e abstrato, conforme formatação do paradigma do Estado de Direito. Conforme Habermas ${ }^{18}$

[...] A tendência à destruição do Estado Social e o surgimento de uma subclasse nas sociedades industriais desenvolvidas carece de uma análise acurada também sob o ponto de vista normativo do recurso efetivo, e sob igualdade de chances, aos direitos de participação política.

O Estado Social tem como escopo a busca de melhoria das condições sociais da comunidade e promoção de justiça social ${ }^{19}$. O surgimento do paradigma do Estado Social se dá ante a incapacidade do Estado Liberal de responder às demandas sociais, cujas garantias dos direitos fundamentais de caráter individual, direitos de primeira geração, previstos teoricamente, na prática, não funcionavam, gerando conflitos sociais. Conforme visão de Pellegrine ${ }^{20}$ :

A passagem do paradigma do Estado Liberal ao Estado Social ocorre em função das demandas sociais, as quais o Estado Liberal mostrou-se completamente incapaz de responder. A mera previsão em textos constitucionais dos princípios da igualdade, liberdade e propriedade não foram suficientes para que os mesmos fossem concretamente garantidos.

\footnotetext{
${ }^{16}$ PELLEGRINI, Flaviane de Magalhães Barros. O paradigma do estado democrático de direito e as teorias do processo. In virtualjus revista eletrônica. Ano 3. julho, 2004, p. 4.

${ }_{17}^{17}$ CATTONI DE OLIVEIRA, Marcelo Andrade. Coesão... op. cit., p. 176.

18 HABERMAS, Jürgen. A inclusão do outro - estudos de teoria política. Tradução George Sperber e Paulo Astor Soethe. São Paulo: Edições Loyola, 2002, p. 367.

19 MEIRELES, Heli Lopes. Direito administrativo brasileiro. 10. ed. atualizada. São Paulo: Ed. Revista dos Tribunais, 1984, p. 497.

20 PELLEGRINE, Flaviane de Magalhães Barros. O paradigma ... op. cit., p. 5. 
Sob o manto do Estado do Bem-estar Social, altera-se o papel do Estado, cabendo-lhe promover o bem-estar social, o equilíbrio e equidade da vida em sociedade, expectativas de comportamento vislumbradas em constituições sociais promulgadas após a Primeira Grande Guerra Mundial, como a mexicana (1917), a alemã [Constituição de Weimar - 1919] ${ }^{21}$. Em Habermas ${ }^{22}$

A república de Weimar fazia parte da tradição de um Estado de direito - já desenvolvido durante a monarquia constitucional - que deveria proteger os cidadãos dos abusos do poder do Estado; contudo, ela integrava, pela primeira vez em solo alemão, o Estado de Direito com a forma de Estado e com o conteúdo político da democracia.

Bem-estar social é traduzido por Hely Lopes Meirelles ${ }^{23}$ como "o bemcomum, o bem do povo em geral, expresso sob todas as formas de satisfação das necessidades comunitárias", abrangendo "as exigências materiais e espirituais, as necessidades vitais dos indivíduos coletivamente considerados". No Estado de Bem-estar Social ocorre a expansão do Estado, no sentido de viabilizar um tratamento jurídico de qualquer situação que vise ao "fim social", na busca pela igualdade e redução da exclusão social. A Constituição Federal de 1988 vislumbra, entre os objetivos fundamentais do Estado, a construção de uma sociedade livre, justa e solidária, a garantia do desenvolvimento nacional, a erradicação da pobreza e da marginalidade, redução das desigualdades sociais e regionais, a promoção do bem de todos, sem preconceitos de raça, sexo, cor, idade e quaisquer outras formas de discriminação (art. $3^{\circ}$ e $\S \S$ ), numa marca evidente do Estado de Bem-estar Social, criado pelo Constituinte de 1988.

Na lição de Hely Lopes Meireles, o Estado de Bem-estar (Welfare State) é um aprimoramento do Estado de Direito.

Não é o Estado Liberal, que se omite ante a conduta individual, nem o Estado Socialista, que suprime a iniciativa particular. É o Estado orientador e incentivador da conduta individual no sentido de bemestar social. Para atingir esse objetivo, o Estado de Bem-Estar intervém na propriedade e no domínio econômico, quando utilizados contra o bem-comum da coletividade.

É sob a tutela do Estado do Bem-estar Social que os direitos sociais e coletivos são definidos e chamados de direitos de segunda geração, acrescidos aos direitos individuais, considerados de primeira geração, que são redefinidos,

21 Ver KÜNG, Hans. Projeto de ética mundial: uma moral ecumênica em vista da sobrevivência humana. Tradução Haroldo Reimer. São Paulo: Paulinas, 1993, p. 49: o autor mostra que sem consenso, adquirido através do diálogo, a democracia não funciona, como no caso da República de Weimar, que existiu de 1919 a 1933 na Alemanha, que resultou no caos.

22 HABERMAS, Jürgen. A inclusão... op. cit., p. 153.

23 MEIRELES, Heli Lopes. Direito... op. cit. p. 497. 
conforme Menelick de Carvalho Neto ${ }^{24}$ :

\begin{abstract}
Não se trata apenas do acréscimo dos chamados direitos de segunda geração (os direitos coletivos e sociais, mas inclusive da redefinição dos de primeira (os individuais); a liberdade não mais pode ser considerada como o direito de se fazer tudo o que não seja proibido por um mínimo de leis, mas agora pressupõe precisamente toda uma plêiade de leis sociais e coletivas que possibilitem, no mínimo, o reconhecimento das diferenças materiais e o tratamento privilegiado do lado social ou economicamente mais fraco da relação ou seja, a internalização na legislação de uma igualdade não mais apenas formal, mas tendencialmente material.
\end{abstract}

Esta co-dependência da sociedade perante o Estado Social acaba gerando um efeito contrário ao pretendido, a saber, a criação de "guetos jurídicos", exemplos da tutela dos direitos dos negros, da criança e do adolescente, das mulheres, dos idosos, entre outros, sem que houvesse a participação efetiva dos afetados pelas normas criadas. Ao invés de proteger estes grupos, acaba por gerar mais exclusão social.

A posição de Chamon Júnior ${ }^{25}$ é de que não é mais sustentável o paradigma do modelo "Estado Social", apesar de reconhecer ser dever do Estado, numa ótica de política deliberativa, "buscar a implementação de políticas públicas ou intervir em certos domínios", desde que esta intervenção

seja deliberada democraticamente, e isto implica abertura capaz de ser travada quando de uma compreensão que seja procedimental do Direito e da Política em que nenhum modelo de sociedade, de valores, de 'interesses coletivos' são tomados como bandeira para a própria exclusão participativa no seio de tomadas de decisão ${ }^{26}$.

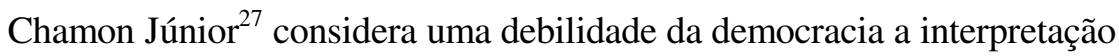
paternalista do "Direito e do Estado", no sentido de uma co-dependência da sociedade, quanto à materialização de suas necessidades. Alerta que não deve ocorrer vinculação de carências materiais no exercício efetivo da democracia, sob o pretexto de que a sociedade ainda não alcançou a realização plena de um Estado de bem-estar, ou seja, de que a "democracia somente será possível, quando tenhamos todos escolaridade, acesso à saúde, à justiça, à moradia, a empregos,

\footnotetext{
24 PELLEGRINE, Flaviane de Magalhães Barros. O paradigma ... op. cit., p. 6.

${ }^{25}$ CHAMON JÚNIOR, Lúcio Antônio. Filosofia do direito na alta modernidade. Rio de Janeiro: Editora Lumen Juris. 2005, p. 270.

${ }^{26}$ CHAMON JÚNIOR, Lúcio Antônio. Tertium non datur: pretensões de coercibilidade e validade em face de uma teoria da argumentação jurídica no marco de uma compreensão procedimental do Estado Democrático de Direito. In Jurisdição e hermenêutica constitucional no estado democrático de direito. Coordenação CATTONI DE OLIVEIRA, Marcelo Andrade. Belo Horizonte: Mandamentos, 2004. Mesma abordagem, também em CHAMON JÚNIOR. Filosofia ... op. cit., nota 6, p. 270.

27 CHAMON JÚNIOR, Lúcio Antônio. Filosofia ... op. cit. p. 271
} 
etc.", sob o fundamento de que "todos temos direitos igualmente e reciprocamente reconhecidos". Requer, outrossim uma consciência política de um povo amadurecido para autodeterminar-se e autogovernar-se, sob o pálio da democracia ${ }^{28}$. Necessário se torna que as pessoas se vejam realmente livres, num Estado organizado de modo a garantir a liberdade de todos e de cada um.

Fundamentando este entendimento, Chamon Júnior ${ }^{29}$ mostra a capacidade da sociedade civil de se organizar e fazer valer seus direitos políticos, exemplificando com o exercício de manifestações populares, ocorridas, recentemente, na Argentina e Venezuela, cuja prática "tende a se fortalecer, se não abafada por práticas coativas arraigadas nas velhas précompreensões ditatoriais que sempre rondam nossa região". Segundo entendimento de Antonio Augusto Cançado Trindade ${ }^{30}$, imprescindível se torna a existência de uma educação dos agentes da lei e das forças policiais e militares, à luz dos direitos humanos que viabilizarão maior proteção, principalmente, dos "segmentos vulneráveis e mais pobres da população", ao lado da existência de um poder judiciário "verdadeiramente eficiente", acessível a todos. Ante estas perspectivas, leciona o autor que "o direito de participação há de fortalecer-se, sobretudo, mediante a educação e auto-organização da sociedade civil com diversas formas de desenvolvimento e atuação das comunidades locais para fortalecer a própria democracia". Neste mesmo sentido, Bernardo Kliksberg ${ }^{31}$ aponta, entre outros, a Villa El Salvador, Peru que, através de iniciativa popular, cooperação, trabalho comunitário e solidariedade, criaram a partir do nada, regras de convivência que geraram para a população envolvida, uma identidade sólida e impulsionaram a auto-estima pessoal e coletiva. No Brasil, o mesmo autor mostra a experiência realizada em Porto Alegre, em 1989, com o Orçamento Participativo. Convidada pelo Prefeito para co-gerir o processo orçamentário da cidade, na época com grave falta de recursos, a população participou ativamente, se organizou e o orçamento foi formado de baixo para cima, numa reação que o autor denomina "febre participativa", melhorando a qualidade de vida de toda a sociedade. O sucesso da experiência foi reconhecido pela Organização das Nações Unidas ONU que a acolheu como uma das quarenta mudanças urbanas eleitas, em todo o mundo, para ser analisada na Conferência Mundial sobre Assentamentos Humanos (Habitat II, de Istambul) e, em 1997, o Instituto de Desenvolvimento Econômico do Banco Mundial realizou uma conferência internacional em Porto Alegre, com a presença de nove países da região para examinarem a experiência.

28 Ver CATTONI DE OLIVEIRA, Marcelo Andrade. Coesão ... op. cit., p. 181.

29 CHAMON JÚNIOR, Lúcio Antônio. Filosofia ... op. cit. p. 270.

30 TRINDADE, Antônio Augusto Cançado. Direitos humanos e meio-ambiente: paralelo dos sistemas de proteção internacional. Porto Alegre: Sergio Antonio Fabris Editor, 1993, p. 210-211.

31 KLIKSBERG, Bernardo. Falácias... op. cit., p. 124-139. 
Para Moore Barrington $\mathrm{Jr}^{32}$ o cidadão comum deve ter direitos de protesto e crítica contra atos injustos, ante a não-satisfação das necessidades sociais. A existência de oposição, em certa medida efetiva, deve persistir, "enquanto a sociedade humana existir, porque toda sociedade humana impõe, necessariamente, muitas frustrações aos desejos e instintos dos indivíduos que a constituem". A saudável manifestação de liberdade de pensamento, de experimentação e de associação, tenta e ousa combinações novas e incomuns; pesquisa e troca de informações entre si; escolhe seu campo de atuação profissional e persegue os próprios interesses, nos dizeres de Moore, e elas devem existir em contexto onde haja ordem, em que necessidades básicas sejam garantidas, uma vez que o mercado implica ordem e liberdade. Neste sentido, leciona Antonio Augusto Cançado Trindade ${ }^{33}$ :

A democracia alimenta e estimula as aspirações a uma melhor qualidade de vida, mas como os problemas econômicos - apesar de todos os sacrifícios sociais impostos à grande maioria da população - não são resolvidos e se agravam, as expectativas são prontamente frustradas. A par da não-observância dos direitos econômicos e sociais, decaem verticalmente os serviços públicos básicos educação, saúde - na medida em que crescem paralelamente a violência em suas múltiplas formas, e o sentido de extrema vulnerabilidade e insegurança pessoais: a vida humana, neste quadro perverso, passa a valer muito pouco, ou quase nada.

Deterioram-se grave e implacavelmente o nível e a qualidade de vida da grande maioria da população, vítima do desastroso fenômeno corrente do empobrecimento geral, o qual atesta a nãoobservância - se não violação - generalizada dos direitos econômicos sociais e culturais. A construção da democracia real e o fortalecimento do Estado de Direito hão de dar-se à luz da interrelação ou indivisibilidade de todos os direitos humanos. Determinados direitos, de caráter econômico e social, como, e.g., o direito a não ser discriminado em relação a emprego e ocupação, e a liberdade de associação para fins sindicais, estão intimamente ligados às chamadas liberdades civis. Outros exemplos podem ser invocados. De que vale o direito a não ser submetido a penas ou tratamentos desumanos ou degradantes sem as garantias do due process? De que vale o direito ao trabalho desprovido de um salário justo, capaz de atender às necessidades humanas básicas? De que vale o direito à vida sem o provimento de condições mínimas de uma existência digna, se não de sobrevivência (alimentação, moradia, vestuário)? [...].

A organização do mercado é, portanto, indispensável para a ordem social. Para que haja livre iniciativa sustentável tem que existir controle do Estado, resultando, conseqüentemente, na produção, na circulação de bens e serviços com previsibilidade e estabilidade das operações. Segundo Barrington Moore Jr. ${ }^{34}$ :

32 MOORE, Barrington Jr. Aspectos... op .cit., p. 118.

33 TRINDADE, Antônio Augusto Cançado. Direitos... op. cit., p. 210.

${ }^{34}$ MOORE, Barrington Jr. Aspectos... op. cit., p. 40. 
Sem garantia de direitos de propriedade e sem garantias de cumprimento de contratos não haverá operações econômicas regulares, pacíficas. Liberdade de contratar, liberdade para dispor da propriedade, liberdade para decidir são marcos fundamentais em qualquer economia de mercado. Restrições a qualquer dessas liberdades decorrem de decisões políticas e, muitas vezes, não são efetivas por dificuldade de ultrapassar barreiras criadas pelas instituições sociais.

Por outro lado, analisando a trajetória histórica brasileira, considerando que o Estado Brasileiro foi colônia de Portugal, marcada por um processo de colonização com o predomínio da exploração do mercantilismo europeu, sem que fossem levadas, em consideração, as especificidades e necessidades locais, aliadas à utilização de mão-de-obra escrava e à formação de oligarquias poderosas, oriundas de fazendas e famílias rurais, nossa cultura foi moldada por práticas de distribuição de favores e na afeição, "em um estilo patrimonialista de gestão da coisa pública, que acabou por definir o modo de fazer política no país, mesmo após a Independência, em 1822, e a constituição da república, em 1889", conforme cita Rosa Maria Fischer ${ }^{35}$. Em nenhum momento, o Estado brasileiro pode configurar-se como o modelo conhecido como welfare state encontrado nos países de economia avançada. Fischer $^{36}$ aponta como causas:

a fragilidade da economia, a precariedade da arrecadação tributária, os critérios de elaboração do orçamento nacional, a amplitude da exclusão social, a baixa capacidade de pressão política das classes populares, a falta de sensibilidade dos técnicos que elaboram e implementam as políticas governamentais.

Ela chegou à conclusão de que jamais existiu, no Brasil, um Estado voltado, prioritariamente, para atender às demandas sociais ou promover ações de desenvolvimento, visando a superar as desigualdades de distribuição de renda e de fruição das benesses do capitalismo. Em Habermas ${ }^{37}$,

Os direitos de cidadania, direitos de participação e comunicação política são, em primeira linha, direitos positivos. Eles não garantem liberdade em relação à coação externa, mas sim a participação em uma práxis comum, por meio de cujo exercício os cidadãos só então se tornam o que tencionam ser - sujeitos politicamente responsáveis de uma comunidade de pessoas livres e iguais.

Chamon Júnior, assim como Habermas, reconhecem a possibilidade da existência da co-dependência em termos de procedimentos, no sentido de que "nossa esfera de liberdades subjetivas somente pode ser legitimamente reconhecida numa esfera pública", dentro de um parâmetro ético e moral.

\footnotetext{
${ }^{35}$ FISCHER, Rosa Maria. O desafio... op. cit., p. 40.

${ }^{36}$ Ibidem.

${ }^{37}$ HABERMAS, Jürgen. A inclusão... op. cit., p. 272.
} 
No ambiente assistencialista, configurado no paradigma do Estado do Bem-estar Social, as empresas enquadram suas condutas, buscam a regularidade funcional tendo em foco seu objeto social, com escopo na lucratividade. Os empregados contam com a satisfação pessoal, fulcro em garantias de direitos trabalhistas. Neste ponto, aparecem as exclusões sociais resultantes de medidas protecionistas do Estado, como é o caso da mulher gestante ${ }^{38}$, que tem a estabilidade provisória, juridicamente protegida em decorrência da gravidez, mas enfrenta o mercado de trabalho fechado, como consequiência desta mesma proteção pretendida pelo Estado que, como norma, corresponde a uma expectativa de conduta.

\section{O EXERCÍCIO DA ATIVIDADE EMPRESÁRIA NO ESTADO DEMOCRÁTICO DE DIREITO ALIADO À PRÁTICA DA RESPONSABILIDADE SOCIAL CORPORATIVA.}

Nas décadas de 60 e 70, registros históricos de manifestações, questionando o paradigma do Estado do Bem-estar Social, a exemplo dos movimentos hippie, estudantis, pacifistas, ecológicos e feministas, mostram, entre outros, a luta pelos direitos das minorias, aliados aos efeitos da Segunda Grande Guerra Mundial, provocam a superação do Estado social.

É no paradigma do Estado Democrático de Direito que, junto aos direitos de primeira e segunda gerações ${ }^{39}$, são introduzidos os de terceira geração, representados pelos direitos difusos, a exemplo da preservação do meio ambiente e das relações de consumo, estes com forte ligação aos resultados do exercício da atividade empresarial. Surge uma visão mais complexa e mais rica de articulação do Estado, da empresa e da sociedade civil, em torno de objetivos, simultaneamente, sociais, econômicos e ambientais.

Ao analisar a Constituição Federal Brasileira atual, percebe-se, em nosso ordenamento, a preocupação com o bem-estar social em seu preâmbulo ${ }^{40} \mathrm{e}$ regulamentos relacionados à ordem econômica e financeira, ao mesmo tempo que estimula a iniciativa privada na busca deste bem-estar social e individual, e a redução da presença do Estado como agente econômico, ao instalar os princípios

\footnotetext{
${ }^{38}$ Ver CATTONI DE OLIVEIRA, Marcelo Andrade. Coesão... op. cit., p. 185-186.

39 Instituídos como uma das bases do Estado Liberal, os direitos de primeira geração consistem em direitos fundamentais de caráter individual. No Estado social são instituídos os direitos de segunda geração, representados pelos direitos sociais, como o de acesso à saúde, ao trabalho, à educação e ao lazer, direito de voto e o direito de greve, conforme Bonavides, 2000, citado por PELLEGRINI, Flaviane Magalhães Barros. A participação da vítima no processo penal e sua sobrevitimização - em busca de uma interpretação constitucionalmente adequada. Belo Horizonte: Pontifícia Universidade Católica de Minas Gerais. Tese de doutorado, 2003.

${ }^{40}$ Constituição Federal de 1988, preâmbulo: "Nós, representantes do povo brasileiro, reunidos em Assembléia Nacional Constituinte para instituir um Estado Democrático, destinado a assegurar o exercício dos direitos sociais e individuais, a liberdade, a segurança, o bem-estar, o desenvolvimento, a igualdade e a justiça como valores supremos de uma sociedade fraterna, pluralista e sem preconceitos, fundada na harmonia social e comprometida, na ordem interna e internacional, com a solução pacífica das controvérsias, promulgamos, [...]".
} 
gerais da atividade econômica fundados na valorização do trabalho humano e na livre iniciativa, objetivando assegurar a todos uma existência digna, conforme os ditames da justiça social (art. 170 da Constituição Federal de 1988, caput). Sobre o tema, assim leciona Eduardo Goulart Pimenta ${ }^{41}$ :

\begin{abstract}
Especificamente em nosso ordenamento, o interesse social na moderna empresa privada, dentro de uma ordem econômica fundada na liberdade de iniciativa (art. 170 da Constituição Federal de 1988, caput), vem se tornando cada vez mais premente, em especial em contexto onde a presença do Estado como agente econômico está diminuindo, ao mesmo tempo em que aumenta a preocupação com a realização dos ditames da justiça social (art. 170 da Constituição Federal de 1988, caput).
\end{abstract}

Na expectativa de conduta no Estado Democrático de Direito, cada ator social deve procurar construir seu bem-estar ao conviver em sociedade, resultando em um conseqüente envolvimento harmonioso dos indivíduos e grupos aos quais eles pertencem, e no reconhecimento da pluralidade ética. Ocorre na abertura e na vivência do social, uma pluralidade de estilos de distintos grupos e no reconhecimento da diferença. Como ressalta Habermas ${ }^{42}$, as minorias "inatas", inseridas em sociedades multiculturais, se organizadas como Estados Democráticos de Direito, "apresentam-se, todavia, diversos caminhos para se chegar a uma inclusão 'com sensibilidade para as diferenças"', numa coexistência com igualdade de direitos de diferentes comunidades étnicas, grupos lingüísticos, confissões religiosas e formas de vida, conformadas numa política geral, uniformemente compartilhada pelos cidadãos. Neste contexto, o ambiente é mais fluídico, mutável, adequável às necessidades atuais dos grupos, numa estrutura que se mantém sempre aberta a revisões. Ocorre uma elaboração mais racional e participativa de todos os valores que são voláteis e incapazes de serem reduzidos e solidificados numa estrutura eterna ${ }^{43}$, ou seja, não existindo um modelo padrão estagnado, são estes revisáveis, mutáveis, adequáveis, num processo legislativo democrático com base na soberania popular.

Sob o sustentáculo da autonomia privada, a sociedade civil organizada intervém na esfera política, no sentido de concretizar suas pretensões jurídicas e éticas, de qualidade de vida, de respeito ao meio ambiente, de geração de um clima de segurança, de preservação do espaço de liberdade e de criatividade

${ }^{41}$ PIMENTA, Eduardo Goulart. Exclusão... op. cit., p. 30.

${ }^{42}$ HABERMAS, Jürgen. A inclusão... op. cit., p. 166.

${ }^{43} \mathrm{O}$ sociólogo ZYGMUNT BAUMAN, fez um interessante estudo sobre a transição da modernidade "pesada" e "sólida" para uma modernidade "leve" e "líquida", infinitamente mais dinâmica. O livro resultante: Modernidade líquida. Tradução, Plínio Dentzien. Rio de Janeiro: Jorge Zahar Ed., 2001, nos mostra o mundo na modernidade, totalmente interligado pelos avanços tecnológicos que propulsionam a vida em sociedade num dinamismo extraordinário, que resulta numa comunicação mais ágil e promove mutações constantes de poder, crenças, necessidades, despertando, segundo Bauman, a autoconsciência, a compreensão e a responsabilidade individuais. O livro mostra a organização da vida humana compartilhada, interativa e que resulta em autonomia e na liberdade individual e de grupos distintos. 
individual e social. O Estado de Direito moderno e constitucional é estruturado, de forma que cada indivíduo seja livre interior e exteriormente, ou seja, a liberdade exterior é assegurada pelas leis, e as organizações sociais e políticas garantem a liberdade individual e o bem comum. Nos dizeres de Pellegrine ${ }^{44}$ :

O Estado passa a ser questionado e fiscalizado a partir da organização da sociedade civil, que exige sua constante participação no debate tanto das coisas públicas como de seus interesses fundamentais. [...] Significa isso a compreensão de um direito participativo, em que a sociedade civil exerce importante papel controlador e conformador do Estado, pluralista, respeitando os diversos matizes sociais, na busca da implantação de direitos, quer de primeira, segunda ou terceira geração, visto como um complexo de direitos e garantias que não podem ser aplicados em separado. Nesse sentido, não importa ter direitos sociais ou, mesmo, proteção aos direitos difusos se não há garantias mínimas de que a atuação estatal, principalmente no âmbito jurisdicional, não atingirá os indivíduos em seus direitos fundamentais.

Representando o Estado neste sentido, o Secretário do Estado do Paraná, Virgílio Moreira Filho ${ }^{45}$, fala da parceria do Estado com entidades, tais como organizações não governamentais e empresas, no sentido de um trabalho em conjunto visando a um desenvolvimento sustentável, com novos focos de atuação, a fim de que os negócios resultantes da atividade empresarial mantenham seus lucros sob o enfoque de um desenvolvimento sustentável, concomitante ao desenvolvimento de um papel social, considerável por parte das empresas, de modo a atenuar seus efeitos e revigorar o mercado, num círculo construtivo onde um depende do outro, numa interatividade de todos em busca do bem-estar de cada um e do grupo a que pertencem. Nos dizeres de Virgílio Moreira Filho ${ }^{46}$ :

O empresário deve buscar o programa de dentro para fora e, assim,
transformar a sociedade a sua volta. Quanto ao Estado, estamos
unidos na proposta de bem-estar para toda a população e estar atrás
dos arranjos produtivos e das cadeias reprodutivas. Assim os
empreendimentos devem ser aqueles que capacitam e aperfeiçoam a
sociedade.

De outro lado, numa visão positivista, hodiernamente, grupos da sociedade civil, em alianças intersetoriais, vêm movimentando-se no sentido de estimular práticas que visem a reduzir a exclusão e promover o desenvolvimento social. O movimento incipiente, na América Latina, vem ganhando força. Vem crescendo o uso de práticas de responsabilidade social entre empresas e terceiro setor, concomitantemente com a criação de fundações que, com personalidade jurídica própria, assumem a missão da implementação de projetos sociais impulsionados pelas empresas institucionalizadoras, ou seja, a responsabilidade

44 PELLEGRINE, Flaviane de Magalhães Barros. O paradigma ... op. cit., p. 7-8.

45 SARMIENTO, Suzana. Evento em Curitiba apresenta experiências bem sucedidas em

Responsabilidade Social. Disponível em <http://www.setor3.com.br/senac2>. Acesso em 14 out. 2005.

46 SARMIENTO, Suzana. Evento... op. cit. 
social corporativa em parcerias que permitem autonomia da atuação dos parceiros envolvidos (empresas representando o segundo setor com associações ou fundações particulares, desempenhando funções do terceiro setor) ${ }^{47}$.

Bernardo Kliksberg ${ }^{48}$ mostra a necessidade da atuação do Estado com outros segmentos da sociedade para promover o desenvolvimento social e aponta o risco do funcionamento do mercado sem a respectiva regulação pelo Estado que resulta no aprofundamento das brechas e desigualdades e nos alerta: "[...] o Estado sozinho não pode resolver os problemas, mas sua minimização agrava-os".

A vida em sociedade torna-se mais estável de forma a suprir as necessidades do povo no decorrer da evolução da vida social, com a participação dos cidadãos, na construção de seus direitos em cumprimento às expectativas de comportamento no Estado Democrático de Direito, conforme ditames da Constituição Federal de 1988, artigo $1^{\circ}$, caput, que insere entre seus fundamentos, a dignidade da pessoa humana, os valores sociais do trabalho e da livre iniciativa, o pluralismo político e, principalmente no parágrafo único ${ }^{49}$, ressalta a importância da participação popular na construção de seus direitos e no controle do poder que resultará num ordenamento jurídico legitima e democraticamente institucionalizado.

Tratando-se de sistema protetivo, portanto, visando à melhoria da qualidade de vida em sociedade, com foco em determinado grupo em situação de risco ou exclusão, tem maior possibilidade de êxito, quando seus destinatários, principais interessados em seu perfeito funcionamento, participam da administração deste e da formulação de novas estratégias sociais. A participação ativa da comunidade ${ }^{50}$ na gestão de assuntos públicos representa os avanços da democratização, produto de longas lutas históricas dos povos que, nos dizeres de Bernardo Kliksberg ${ }^{51}$, representam "exigências crescentes das grandes maiorias da sociedade na América Latina e em outras regiões". Para o mesmo autor:

[...] os programas sociais fazem melhor uso dos recursos, conseguem ser bem-sucedidos no alcance de suas metas e criam auto-sustentabilidade, se as comunidades pobres às quais se deseja favorecer participam desde o início e ao longo de todo o seu desenvolvimento e compartilham do planejamento, da gestão, do controle e da avaliação. [...] A comunidade multiplica os recursos escassos, somando a eles incontáveis horas de trabalho, e é geradora

\footnotetext{
${ }^{47}$ ROSA MARIA FISCHER em seu livro O desafio da colaboração - práticas de responsabilidade social entre empresas e terceiro setor. São Paulo: Editora Gente, 2002, realizou interessante trabalho investigativo, interpretando dados sobre as alianças estratégicas intersetoriais mapeados nas pesquisas realizadas no CEATS - Centro de estudos em administração do terceiro setor, da USP, com levantamentos de campo e descrições e análises e casos, num processo centrado na compatibilidade entre a teoria e a prática, entre a fundamentação acadêmica e a realidade empírica.

${ }^{48}$ KLIKSBERG, Bernardo. Falácias... op. cit., p. 33.

${ }^{49}$ Parágrafo único do art. $1^{\circ}$ da Constituição Federal de 1988: "todo o poder emana do povo, que o exerce por meio de representantes eleitos ou diretamente, nos termos desta Constituição".

${ }^{50}$ Ver CATTONI DE OLIVEIRA, Marcelo Andrade. Coesão... op. cit.

51 KLIKSBERG, Bernardo. Falácias... op. cit., p. 39-41.
} 
de contínuas iniciativas inovadoras. Além disso, a presença da comunidade é um dos poucos meios que previne efetivamente contra a corrupção. ${ }^{52}$

Kliksberg $^{53}$ aponta diversos dados e pesquisas sobre a superioridade gerencial da participação comunitária em seus livros: 1. Falácias e mitos do desenvolvimento social; 2. Seis teses no convencionales sobre participación em instituciones y desarrollo. Em referência à constatação de Stern, economistachefe do Banco Mundial, após múltiplos estudos da instituição sobre o assunto (2000), o autor declara:

Ao longo do mundo, a participação funciona: as escolas operam melhor se os pais participam, os programas de irrigação são melhores se os camponeses participam, o crédito trabalha melhor se os solicitantes participam. As reformas dos países são muito mais efetivas se forem geradas no país e dirigidas pelo país. A participação é prática e poderosa ${ }^{54}$.

Entretanto, esta é uma falácia apontada por Kliksberg que impede o desenvolvimento social com a participação da grande massa popular, num claro divórcio entre o discurso e a realidade, representada por "falsas promessas" fato percebido pela população, cuja constatação gera descontentamento e frustração. Segundo o autor, por um lado "existem resistências profundas de que definitivamente as comunidades pobres participem, que se disfarcem diante de sua ilegitimidade conceitual, política e ética"; por outro, a situação agrava-se no interior dos Estados regionais e dos municípios com diversos casos de "oligarquias" locais, pequenas, "que controlam, desde tempos imemoriais, o funcionamento da sociedade local, direcionando projetos em seu próprio interesse". Necessário se faz que sejam realizados trabalhos no sentido de capacitar recursos humanos locais com o propósito de dirigir os programas sociais sem entraves burocráticos e políticos tendenciosos.

52 Ver FISCHER, Rosa Maria. O desafio... op. cit., p. 16.

53 KLIKSBERG, Bernardo. Falácias... op. cit., p. 40.

${ }^{54}$ KLIKSBERG, Bernardo. Falácias... op. cit., p. 40 aponta dois recentes trabalhos efetuados em 2000 pelo PNUD, Superando a pobreza, e pelo Banco Mundial, The voices of the poor, baseado numa gigantesca pesquisa com 60 mil pobres de 60 países, chegam a similar conclusão em termos de políticas: É preciso dar prioridade para investir e fortalecer as organizações dos próprios pobres. Eles carecem de "voz e voto" real na sociedade. Fortalecer suas organizações lhes permitirá participar de modo muito mais ativo e recuperar terreno em ambas as dimensões. Propõe-se, entre outros aspectos: facilitar sua constituição, apoiá-las, dar possibilidades de capacitação a seus líderes, fortalecer suas capacidades de gestão. A constatação é de que, na América Latina, "continuam predominando os programas impostos 'chave na mão' e impostos verticalmente, onde quem tem poder de decisão ou os que desenham são aqueles que sabem e a comunidade desfavorecida deve acatar suas diretivas e ser sujeito passivo deste. Também são comuns os programas em que se fazem fortes apelos quando se trata de programas participativos, quando na verdade há um mínimo conteúdo real de intervenção da comunidade na tomada de decisões. O discurso diz 'sim' à participação na região, mas os fatos com freqüência dizem 'não". 
Neste contexto, Kliksberg sugere seja feita, pelo Estado, uma revolução organizacional, para transformá-lo num Estado Social inteligente, com a substituição da "cultura burocrática atual aberta ou sorrateiramente antiparticipativa por uma cultura realmente interessada na participação e disposta a promovê-la".

Para que o crescimento signifique bem-estar coletivo, deve haver, simultaneamente, desenvolvimento social. O bem-estar social é o escopo da justiça social a que se refere nossa constituição (artigo 170), e só pode ser alcançado através do desenvolvimento nacional. Kliksberg sublinha que a interrelação Estado-comunidade deve ser articulada pelo Estado e reconhece que "a realidade social é tão difícil, que, em primeiro lugar, exige-se, imperativamente, a responsabilidade de todos os atores sociais". Todos devem cooperar, incluindo Estado, sociedade civil, nela inserida os cidadãos, segundo e terceiro setores. É um entendimento de, entre outros, Kliksberg e Chamon Júnior, porque concerne a todos o que vai acontecer, sob o fundamento de que o ordenamento jurídico, legitimamente instituído, através de procedimentos de formação democrática da opinião e da vontade, fundamentam a suposição da aceitabilidade racional dos resultados pelos cidadãos ${ }^{55}$.

Em decorrência de seu estudo sobre as falácias e mitos do desenvolvimento social, Bernardo Kliksberg ${ }^{56}$ alerta a sociedade civil para a encruzilhada histórica em que a América Latina se encontra ante o problema do aumento da delinqüência, questionando qual direcionamento a ser trilhado, ou seja:

\footnotetext{
Por qual caminho optará? O que vai em direção à criminalização da pobreza ou o da integração social? Cabe aprofundar na democracia este debate transcendental, substituir os slogans e medidas de fachada por dados sérios, identificar as causas estruturais do problema e ter em conta que aí está em jogo, nada mais nada menos, do que a qualidade moral básica de nossas sociedades.
}

O Estado, como agente regulador da economia, é de vital importância para a promoção da estabilidade e segurança social. A intervenção estatal moderada, como instrumento jurídico para ordenar atividades econômicas, é necessária, no sentido de reduzir falhas nos mercados, falhas estas que, conforme Rachel Sztajn ${ }^{57}$, tendem a comprometer o bem-estar das pessoas.

Falando sobre as possibilidades de democracia em um país que depende de uma base social independente do governo, Barrington Moore Jr. ${ }^{58}$ estabelece algumas condições como a ampla difusão da propriedade entre a população,

55 HABERMAS, Jürgen. A era das transições. Tradução e introdução Flávio Siebeneichler. Rio de Janeiro: Tempo Brasileiro, 2003, p. 153-154.

${ }^{56}$ KLIKSBERG, Bernardo. Falácias... op. cit., p. 166.

57 SZTAJN, Rachel. Teoria jurídica da empresa: atividade empresária e mercados. São Paulo: Atlas, 2004, p. 52.

58 MOORE, Barrington Jr. Aspectos... op. cit. p. 131.

Revista de Estudos Jurídicos, a. 15, n. 22, 2011 
aliada à capacidade técnica laboral e uma economia em razoáveis condições de funcionamento. Moore se baseia no entendimento de que "um sistema econômico que priva uma parte substancial da população de suas fontes de sustento, por meio do desemprego, no caso dos assalariados e da perda da propriedade da terra pelos fazendeiros e camponeses, provocará um enorme sofrimento e amargura", resultando perda de lealdade política.

A atividade empresarial tem interesse social, pois, como nos dizeres de Rachel Sztajn ${ }^{59}$ : é uma das razões que justificam a promoção de trocas eficientes, porque isto aumenta o bem-estar das pessoas e mostra a necessidade da intervenção moderada do Estado no domínio econômico com mecanismo de controle de mercados e, em seguida, com a busca de redução de riscos ou incentivos a certas pessoas ou setores da atividade econômica.

A solução encontrada por Moore ${ }^{60}$, quanto ao que se pode fazer para inibir o comportamento anti-social, por parte de algum segmento da sociedade, capaz de gerar instabilidade social, seria "montar um sistema adequado de recompensas em troca de um comportamento desejado, e penalidades para comportamentos indesejáveis, e esperar pelos resultados que logo estarão evidentes". Posicionamento similar é o adotado por Armando Castelar Pinheiro e Jairo Saddi ${ }^{61}$, ao analisarem incentivos ao comportamento, com vistas ao cumprimento de contratos. Conforme os autores, os incentivos devem ter conotação financeira - monetária por excelência, já que a tendência dos agentes econômicos é de reduzir os custos da transação e seus impactos. Interpretam a lei como um contrato entre a sociedade e o cidadão, "que busca criar um sistema de incentivos (majoritariamente calcado em penalidades) capaz de alinhar os objetivos individuais aos do coletivo social", tendo em vista o entendimento que o direito é prescritivo, "uma vez que estabelece normas de condutas que devem ser seguidas por todos e se vale de mecanismos de coação e sanção no seu descumprimento". Neste prisma, se o sistema jurídico for eficiente, com decisões judiciais uniformes a respeito de condutas que desafiam suas diretrizes, serve de incentivos e desincentivos como orientação para um comportamento correto do cidadão.

\section{TRANSIÇÃO DA DEMOCRACIA REPRESENTATIVA PARA A PARTICIPATIVA.}

Tem o Estado brasileiro, como meta principal, "assegurar o exercício dos direitos sociais e individuais; a liberdade, a segurança, o bem-estar, o desenvolvimento, a igualdade e a justiça como valores supremos de uma sociedade fraterna, pluralista e sem preconceitos, fundada na harmonia social e

59 SZTAJN, Rachel. Teoria ... op. cit. p. 43.

60 MOORE, Barrington Jr. Aspectos... op. cit. p. 161.

61 PINHEIRO, Armando Castelar; SADDI, Jairo. Direito, economia e mercados. Rio de Janeiro: Elsevier, 2005, p. 141. 
comprometida com a ordem interna e internacional, buscando-se a solução pacífica das controvérsias". 62

Lembrando a tese defendida por Habermas, analisada por Cattoni de Oliveira $^{63}$, de que "não há Estado de Direito sem democracia" e que "o Direito moderno legitima-se a partir da autonomia garantida igualmente a todo cidadão [...]", para o Estado brasileiro atuar como Estado Democrático de Direito, ele o faz através de representantes eleitos pelo povo, por meio dos poderes constituídos, considerados, globalmente, como órgãos de soberania nacional, seguindo sistematização proposta, inicialmente, por Montesquieu ${ }^{64}$. Ante a impossibilidade de todo homem governar a si próprio, criando leis que o atendam particularmente, Montesquieu $^{65}$ propõe, como forma de liberdade política, "que o povo exerça pelos seus representantes tudo aquilo que não possa praticar por si mesmo". É o governo do povo, pelo povo e para o povo. Em seu livro - De L'Esprit des Lois, editado pela primeira vez em 1748 , ensina que

[...] A liberdade política, num cidadão, é essa tranqüilidade do espírito que provém da opinião que cada um possui de sua própria segurança; e, para que se possua essa liberdade, é preciso que o governo seja tal que um cidadão não possa temer a um outro [...].

Conforme o parágrafo único do artigo $1^{\circ}$ da Constituição Federal de 1988, "in verbis": "Todo poder emana do povo, que o exerce por meio de representantes eleitos ou diretamente, nos termos desta Constituição". Hodiernamente, a democracia representativa abre espaço para a de caráter participativo, na qual as pessoas emitem parecer sobre assuntos políticos que os afetarão $^{66}$. Segundo Idalberto Chiavenato ${ }^{67}$, está, em curso, uma revolução política na qual "as pessoas cujas vidas são afetadas por uma decisão, devem fazer parte do processo de se chegar a esta decisão". A sociedade atual, de governo democrático, tende ao pluralismo, com diversos centros de poder, embora, ainda, com a prevalência do poder oligárquico. Reproduzindo a fala de Idalberto Chiavenato ${ }^{68}$ "a decorrência maior dessa passagem da democracia

62 Conforme preâmbulo da Constituição Federal Brasileira de 1988.

63 CATTONI DE OLIVEIRA, Marcelo Andrade. Coesão... op. cit., p. 173.

64 MONTESQUIEU, Charles-Louis de Secondat, Barão de La Brède et de. Do espirito das leis. Tradução: Gabriela de Andrada Dias Barbosa. Introdução: Otto Maria Carpeaux, com anotações de Voltaire, de Crévier, de Mably, de La Harpe, etc. Edições de Ouro. Título original francês: De L'Esprit dês lois. Direitos cedidos por Edições e Publicações Brasil Editora S.A., Vol. 1. Livro décimo-primeiro. Capítulo VI.

Ver PINHEIRO, Armando Castelar; SADDI, Jairo. Direito... op. cit., p. 8.

65 MONTESQUIEU. Do espírito ... op. cit. p. 205.

66 Ver SANTOS, Boaventura de Sousa. O fórum Social Mundial: manual de uso. São Paulo: Cortez, 2005.

67 CHIAVENATO, Idalberto. Teoria geral da administração. Volume 1. $6^{\mathrm{a}}$ ed. Rio de Janeiro: Campus, 1999, p. 23.

${ }^{6}$ CHIAVENATO, Idalberto. Teoria... op. cit., p. 23. Ver ainda VELOSO, Letícia Helena Medeiros. Responsabilidade social empresarial: a fundamentação na ética e na explicitação de princípios e 
representativa para a democracia participativa será a maior influência dos membros da empresa, em todos os seus níveis", fator que provoca a necessidade de redução de diferenças hierárquicas internas, conseqüentes de modelo administrativo, anteriormente estruturado em formatação piramidal e centralizador. Mesmo entendimento é o de Bernardo Kliksberg. Após vinte anos de pesquisa sobre as diferenças sociais da América Latina, constata que, atualmente, há uma vigorosa pressão, para que a participação popular adquira características cada vez mais pró-ativas. Aspira-se substituir, segundo o autor, a democracia passiva por uma inteligente, onde o cidadão esteja amplamente informado, disponha de múltiplos canais para transmitir seus pontos de vista - e não através da eleição das autoridades máximas, de tantos em tantos anos - e exerçam uma influência real e constante sobre a gestão dos assuntos públicos. A participação ativa da sociedade civil, na solução de seus problemas, como um processo social, transforma seus próprios atores. Segundo Kliksberg, isto gera o efeito de empoderamento dos grupos favorecidos; faz crescer a confiança em suas próprias capacidades e contribui para a sua articulação, constituindo elementos que, em sua totalidade, colocam estes grupos em melhor situação, para lutarem por seus direitos e influírem, de modo efetivo, no meio em que vivem ${ }^{69}$.

Relevando a experiência participativa, no âmbito das organizações, Idalberto Chiavenato ${ }^{70}$ leciona ainda:

\begin{abstract}
Durante séculos, os empreendimentos humanos foram organizados e administrados dentro de uma estrutura hierárquica de conformação piramidal e centralizadora. Em função das restrições, conservantismo e rigidez desse modelo autocrático e impositivo, no qual predomina a comunicação vertical e descendente, as pessoas foram forçadas a interagir umas com as outras, criando a organização informal, em outros termos, exercendo a comunicação lateral ou horizontal. Este processo gera redes informais de comunicação que se superpõem à malha formal, ultrapassando-a no tempo e no espaço. Essas redes são mais ágeis e diretas, mais ricas e profundas, levando a um maior contato humano entre as pessoas.
\end{abstract}

A organização hierárquica e piramidal frustra e aliena as pessoas, pois a autoridade única (ou unidade de comando) restringe a comunicação da pessoa,

valores. In Ética e responsabilidade social nos negócios. Coordenação Patrícia Almeida Ashley. 2. ed. São Paulo: Saraiva, 2006.

${ }^{69}$ Ver exemplo da Fundação Acesita com a interatividade da sociedade e que resultou numa melhoria substancial da qualidade do ensino regional, ampliação das oportunidades de formação profissional e geração de renda para famílias carentes, estímulo ao artesanato e microprodutores agrícolas da região, viabilizando produção e comercialização de bens, tendo como resultado o desenvolvimento da comunidade e o fortalecimento no mercado da imagem institucional [da empresa]. Case in FISCHER, Rosa Maria. O desafio... op.cit. Ver ainda: experiências da Vila El Salvador, no Peru, as Feiras de Consumo Familiar, na Venezuela, e o Orçamento Municipal Participativo, em Porto Alegre, Brasil, considerados casos exemplares de sucesso e, atualmente, referência internacional. Cases in KLIKSBERG, Bernardo (Org.). Capital social y cultura: claves estratégicas para el desarrollo. Buenos Aires: Ediciones Fondo de Cultura Econômica, 2000.

${ }^{70}$ CHIAVENATO, Idalberto. Teoria... op. cit., p. 23 
afetando negativamente, o seu comprometimento com a organização. As estruturas tradicionais tornam-se inadequadas para as complexas empresas de hoje que têm que se adaptar a padrões globais de produção. A tendência atual é a de ganhar espaço os modelos de administração mais flexíveis, adequáveis às diversas culturas, atendendo às exigências ambientais e com comportamentos obedecendo a valores morais, universalmente aceitos ${ }^{71}$. Segundo gestão voltada para o capital intelectual (ou de capital humano), sob a análise de Idalberto Chiavenato $^{72}$ :

\begin{abstract}
A comunicação lateral intensiva será a maneira de garantir o suprimento do recurso então mais importante: a informação. Esta tendência para a comunicação lateral intensiva provocará certamente uma maior visibilidade e transparência das empresas. Enquanto crescem, a influência ambiental que exercem necessariamente aumenta. Isto faz com que as empresas chamem mais a atenção do ambiente e do público e passem a ser mais visíveis e percebidas pela opinião pública. Aumenta, assim, a sua visibilidade. Porém, enquanto se tornam mais intensivas as comunicações laterais, aumenta a transparência das empresas. Isto faz com que os eventos internos passem facilmente ao conhecimento de estranhos ou elementos externos. Assim, a visibilidade da empresa - a sua capacidade de chamar a atenção - e a sua transparência - a capacidade de se revelar - podem ocorrer de muitas maneiras positivas ou negativas. Mas o que não permite dúvidas é o fato de que a empresa jamais será ignorada. E a sua visibilidade e transparência causarão enorme impacto em sua estrutura e seu comportamento.
\end{abstract}

À medida que o ambiente se torna mutável, dinâmico e incerto, as empresas precisam ser inovadoras, flexíveis, orgânicas, ou seja, precisam mudar suas feições internas, com tal freqüência, que os cargos e departamentos são, constantemente, revistos e redefinidos.

\title{
5. O PAPEL DO ESTADO NA PROMOÇÃO DO BEM-ESTAR SOCIAL.
}

Objetivando o alcance interno do equilíbrio social, do bem-estar social, da justiça social, na vida do povo brasileiro, o Estado-nação se organiza em estruturas com vínculos atributivos, traduzidos, de um lado, pela administração pública direta [exercida por entidades políticas, através de seus órgãos, de acordo com sua estrutura organizacional], de funções básicas indelegáveis e, com vistas, a viabilizarem o intervencionismo estatal no limite necessário ao atendimento do reclame social. A outra forma de atuação do Estado-nação se faz por meio da administração pública indireta [exercida por entes públicos, dotados de

71 Ver BAUMAN, Zygmunt. Modernidade líquida. Tradução Plínio Dentzien. Rio de Janeiro: Jorge Zahar, 2001.

${ }^{72}$ CHIAVENATO, Idalberto. Teoria... op. cit., p. 24.

Revista de Estudos Jurídicos, a. 15, n. 22, 2011 
personalidade jurídica própria, criados ou mantidos pelo Estado, com o propósito de prestarem serviços públicos ou de interesse público delegável].

Segundo preceitos constitucionais vigentes, podemos enumerar como objetivos fundamentais do Estado-nação no campo interno: construir uma sociedade livre, justa e solidária; garantir o desenvolvimento nacional; erradicar a pobreza, a marginalização e reduzir as desigualdades sociais e regionais; promover o bem de todos, sem preconceitos de origem, raça, sexo, cor, idade ou quaisquer outras formas de discriminação ${ }^{73}$.

Quanto à atuação do Estado, tendo em vista a responsabilidade social corporativa, Fábio Konder Comparato ${ }^{74}$ mostra sua preocupação no sentido de que ele entende caber, principalmente, ao Estado, a iniciativa de promover o bemestar social.

A tese da função social das empresas apresenta hoje o sério risco de servir como mero disfarce retórico para o abandono, pelo Estado, de toda política social, em homenagem à estabilidade monetária e ao equilíbrio das finanças públicas. Quando a Constituição define como objetivo fundamental de nossa República "construir uma sociedade livre, justa e solidária (art. $3^{\circ}, \mathrm{I}$ ), quando ela declara que a ordem social tem por objetivo a realização do bem-estar e da justiça social (art. 193), ela não está certamente autorizando uma demissão do Estado, como órgão encarregado de guiar e dirigir a nação em busca de tais finalidades.

Bernardo Kliksberg ${ }^{75}$ nos mostra a necessidade da atuação do Estado em parceria com outros segmentos da sociedade, para promoverem o desenvolvimento social e aponta o risco do funcionamento do mercado sem a respectiva regulação pelo Estado, que resulta no aprofundamento das brechas e desigualdades, e alerta: "[...] o Estado sozinho não pode resolver os problemas, mas sua minimização agrava-os". Este cenário é visto por Mcintosh et alii ${ }^{76}$ que apontam como único caminho para a construção de comunidades sadias e seguras, o trabalho em conjunto entre governo, sociedade civil e negócios. Sem essa parceria, cada setor, por si só, não é auto-suficiente para atender às necessidades sociais no contexto atual. E justificam: "Da mesma forma pela qual os governos não podem solucionar os problemas do mundo sozinhos, sem mercados para motivar, inovar e inspirar, não se pode esperar que os negócios o façam sozinhos". Fazendo referência à lição de Charles Handy ${ }^{77}$, complementam: "O capitalismo não tem capacidade de fornecer uma vida boa para todos, nem

${ }^{73}$ Ver GRAU, Eros Roberto. A ordem econômica na Constituição de 1988: interpretação crítica. 9. ed. São Paulo: Malheiros, 2004.

74 COMPARATO, Fábio Konder. Estado, empresa e função social. Revista dos Tribunais, São Paulo: Revista dos Tribunais, ano 85, n. 732, out. 1996. p. 46.

75 KLIKSBERG, Bernardo. Falácias... op. cit., p. 33.

76 MCINTOSH, Malcolm et alii; Cidadania corporativa: estratégias bem-sucedidas para empresas responsáveis. Tradução de Bazán Tecnologia e Linguística. Rio de Janeiro: Qualitymark ed., 2001, p. 18-19.

77 MCINTOSH, Malcolm et alii; Cidadania... op. cit., nota 38. 
uma sociedade decente. Não penso que devemos esperar que o faça. Ele é um meio, não um fim".

Reconhecendo a atribuição primordial do Estado, quanto ao desenvolvimento social, mas, também, quanto à importância da atuação em parceria, com respectiva co-responsabilidade entre os atores sociais, Fernando Mânica ${ }^{78}$ entende a prática da responsabilidade social uma inter-relação entre Estado, empresas e sociedade, em relações recíprocas:

Responsabilidade social é uma expressão recentemente adotada para referir-se ao modo como o Estado, as empresas e a sociedade se comportam em suas relações recíprocas. Compõem o conceito de responsabilidade social os padrões de ética, moralidade, transparência e altruísmo que permeiam a conduta dos atores sociais.

Por outro lado, atentando para o fim econômico da atividade empresarial, quando, por seu exercício efetivo e regular, a empresa produz bens e riquezas, gera empregos, paga tributos e encargos sociais e, assim, já está contribuindo para o desenvolvimento social, ou seja, cumpre sua função social. Além disto, deve a empresa desempenhar outro papel na promoção do bem-estar social, paralelo ao seu objetivo de lucro como resultado da atividade empresarial? Sérgio Botrel ${ }^{79}$ entende que não, sob o argumento de que o exercício de atividades no mercado, em conformidade com as diretrizes constitucionais "não impõem ao empresário qualquer tipo de dever assistencialista, não constituindo dever daqueles que desenvolvem a livre iniciativa promover a busca do pleno emprego ou reduzir as desigualdades regionais e sociais. Esses deveres competem ao Estado".

Em oposição à doutrina de posicionamento conservador, encabeçada por Milton Friedman e, ideologicamente integrado nos termos da corrente doutrinária modernista, defendida por Andrew Carnegie [1899], para Bernardo Kliksberg ${ }^{80}$, em contraposição do que, segundo ele, comumente ocorre na América Latina, existe uma tendência das empresas para a prática da responsabilidade social corporativa nos países desenvolvidos. Conforme seu depoimento:

\footnotetext{
Aumentou no mundo desenvolvido a participação empresarial no apoio à ação social da sociedade civil. As contribuições e iniciativas empresariais de solidariedade foram incrementadas e o crescimento de sua responsabilidade social passou a fazer parte cada vez maior da legitimidade da própria empresa. A afirmação feita há anos por Milton Friedman, o guru da Escola de Chicago, de que a única responsabilidade da empresa privada é produzir utilidades para seus acionistas, tem sido refutada constantemente por empresários proeminentes e é hoje rejeitada maciçamente pela opinião pública

78 MÂNICA, Fernando. Entrevista para responsabilidadesocial.com. Edição: 31. Ano: 2 ISSN: 16774949. Extraída do site: http://www.responsabilidadesocial.com . Acesso em 18 de ago. 2005.

${ }^{79}$ BOTREL, Sérgio. Direito societário constitucional: uma proposta de leitura constitucional do direito societário. São Paulo: Atlas, 2009, p. 59.

80 KLIKSBERG, Bernardo. Falácias... op. cit. p. 37.
} 
dos países desenvolvidos. Na América Latina, a situação tende a ser muito diferente $[\ldots]$.

No exercício de suas atividades, as empresas partem para a prática de marketing social, com projetos sociais que suprem necessidades de determinados grupos, tendo, como foco, a conquista de mercado, ou seja, usam de estratégia empresarial com objetivo de garantir sucesso econômico a longo prazo. Os projetos sociais assim direcionados são suportes para sustentabilidade da atividade empresarial, na conquista do público consumidor.

O ânimo dos cidadãos, envolvidos neste contexto, na concepção de Habermas ${ }^{81}$ tem origem em um "ethos democrático", motivado por virtudes civis, "mesmo que essas orientações generalizadas de valor não decidam, previamente, sobre normas em particular." São atos voltados para suprimento de questões éticas, que simbolizam o que é útil e bom para o grupo e para a sociedade, entretanto não são capazes de ser impostos ou determinados por outrem ${ }^{82}$. Neste sentido e no entendimento de Habermas ${ }^{83}$ "pode-se sugerir aos cidadãos que se orientem segundo o bem comum, mas não se pode transformar tal orientação em obrigação jurídica". A relação entre Direito e Moral é de complementaridade e não de subordinação, devendo o Direito estar sempre em consonância com a Moral.

\section{CONCLUSÃO}

O que se percebeu, ao longo deste trabalho, é que a alteração das relações de mercado, em virtude dos efeitos provocados por alarmantes indicadores sociais, marcados pela desigualdade de distribuição de renda e de oportunidades de ascensão social, nas últimas décadas, aclarada no Brasil, principalmente, pósregime militar, a pobreza passa a ser percebida como uma ameaça à ordem social e de desvigoramento do mercado.

${ }^{81}$ HABERMAS, Jürgen. A inclusão... op. cit., p. 301.

${ }^{82}$ As normas SA 8000 e NBR 16000 representam sistemas de gestão para dirigir e controlar uma organização no que diz respeito à responsabilidade social; a primeira contém requisitos para a certificação, a segunda objetiva "prover às organizações os elementos de um sistema da gestão da responsabilidade social eficaz, passível de integração com outros requisitos de gestão, de forma a auxiliá-las a alcançar seus objetivos relacionados com os aspectos ambientais, econômicos e sociais, permitindo à organização formular e implementar uma política e objetivos que levem em conta os requisitos legais e outros, seus compromissos éticos e sua preocupação com a promoção da cidadania, transparência de suas atividades; e promoção do desenvolvimento sustentável". São sugestões de procedimentos sem sanções pelo seu não acolhimento. Descreve OCEANO ZACHARIAS que os requisitos de responsabilidade destas normas são: 1 . Trabalho infantil; 2. Trabalho forçado; 3. Segurança e saúde no trabalho; 4. Liberdade de associação e direitos coletivos; 5. Discriminação; 6. Práticas disciplinares; 7. Carga horária de trabalho; 8. Remuneração; 9. Sistema de gestão. - ZACHARIAS, Oceano. SA 8000 - Responsabilidade social - NBR 16000 - Estratégia para empresas socialmente responsáveis. São Paulo: Editora EPSE, 2004, p. 48 a 61 e 70. Ver também: SROUR, Robert Henry. Ética empresarial: a gestão da reputação. 5. tiragem. Rio de Janeiro: Elsevier, 2003. p. 37-38.

${ }^{83}$ HABERMAS, Jürgen. A inclusão... op. cit., p. 302. Ver CATTONI DE OLIVEIRA, Marcelo Andrade. Coesão... op. cit., p. 177. 
A Constituição Federal de 1988, inicialmente, conformando um Estado Social, define os direitos dos cidadãos, e declara a função social da propriedade. A formatação constitucional atual estimula o envolvimento da sociedade, para que contribua no sentido de minimizar os efeitos das múltiplas carências sociais, sob a mediação interventiva e gerencial do Governo, devendo este assegurar o bom funcionamento do mercado, "status" que tem conduzido a uma redefinição de papéis de cada ator social, no alcance do bem comum, provocando um fortalecimento do terceiro setor, cujo crescimento pode ser observado, não apenas pelo aumento significativo de organizações sem fins lucrativos, também nos recursos mobilizados e nas ações sociais empreendidas em programas sociais, em evidente crescimento de alianças intersetoriais, com vistas ao desenvolvimento sustentável e ao fortalecimento da sociedade civil, conduzindo-a para a democracia participativa como valor universal.

Partimos do pressuposto de que, no contexto de um Estado Democrático de Direito, a responsabilidade social é atribuição inerente a todos: indivíduos, grupos familiares, organizações, governos, como partícipes do processo de crescimento organizado e da evolução do povo do qual fazemos parte.

Inseridas neste mercado competitivo, as empresas precisam promover sua boa imagem, valorizarem suas marcas, reforçarem sua credibilidade e estarem atentas às reações do mercado. São estratégias administrativas, que orientam suas atitudes no mercado, posturas essas, de adequação, que geram valores e resultam em condicionamento para continuarem bem sucedidas.

Não podem ser desconsiderados fatores importantes como o desenvolvimento socioambiental sustentável, quando pensamos no exercício de atividades econômicas, por atores inseridos num contexto social, com suas respectivas responsabilidades, numa rede de relacionamentos, sob a égide de princípios éticos universais.

A função social da empresa está associada ao exercício da atividade empresarial que gera riqueza e emprego, e, por consequência, interage com a sociedade. É o reflexo das atividades econômicas na sociedade e no meio ambiente.

\section{REFERÊNCIAS}

ALMEIDA, Amador Paes de. Direito de empresa no código civil. São Paulo: Saraiva, 2004.

ANANIAS, Patrus. Novos paradigmas (opinião). Fonte: Veículo: Estado de Minas Belo Horizonte - MG. Data publicação: 08 jun. 2006.

ARNOLDI, Paulo Roberto Colombo; MICHELAN, Taís Cristina de Camargo. Novos enfoques da função social da empresa numa economia globalizada. São Paulo: Ed. Revista dos Tribunais; julho-setembro de 2002.

ASCARELLI, Tullio. Panorama do direito comercial. São Paulo: Saraiva, 1947. 
ASHLEY, Patrícia Almeida. A mudança histórica do conceito de responsabilidade social empresarial. In Ética e responsabilidade social nos negócios. Coordenação Patrícia Almeida Ashley. 2. ed. São Paulo: Saraiva, 2006.

BATALHA, Wilson de Souza Campos. Comentários à lei das SA. Rio de Janeiro: Forense, 1977.

BAUMAN, Zygmunt. Globalização: as conseqüências humanas. Tradução de Marcus Penchel. Rio de Janeiro: Jorge Zahar Editor, 1999. Zahar, 2001. Modernidade líquida. Tradução Plínio Dentzien. Rio de Janeiro: Jorge

BERNARDO, João. Democracia totalitária: teoria e prática da empresa. São Paulo: Cortez, 2004.

BLAZER, Maria Fernanda. Número de novos nomes incluídos no SPC dobrou em quase um ano. disponível no site:

<http://oglobo.globo.com/economia/mat/2006/08/17/285323351.asp>. Acesso em 18 ago. 2006.

BONAVIDES, Paulo. Curso de direito constitucional. São Paulo: Malheiros, 2001. BORBA, José Edwaldo Tavares. Direito Societário. 9. ed. revisada, aumentada e atualizada. Rio de Janeiro: Renovar, 2004.

Parecer do Dr. Tavares Borba sobre sociedade simples. Disponível em: $<$ http://www.irtdpjsaopaulo.com.br/ParecerBorba.htm> Acesso em 10 jan. 2006.

BOTREL, Sérgio. Direito societário constitucional: uma proposta de leitura constitucional do direito societário. São Paulo: Atlas, 2009.

BUENO, Francisco da Silveira. Grande dicionário etimológico e prosódico da língua portuguesa. São Paulo: Brasília, 1974.

BULGARELLI, Waldirio. Direito Comercial. 10. ed. São Paulo: Atlas, 1993.

CAMPINHO, Sérgio. $\mathbf{O}$ direito de empresa à luz do novo Código Civil. $11^{\mathrm{a}} \mathrm{ed}$. Revista e atualizada de acordo com a Lei n ${ }^{\circ}$ 11.941/2009. Rio de Janeiro: Renovar, 2010.

CARAMICO, Mauro. As sociedades simples. Disponível em $<\mathrm{http}: / /$ www.migalhas.com.br/mostra_noticia_articuladas.aspx? $\mathrm{cod}=2511>$. Acesso 06 nov. 2005.

CARSON, Robert B. O que os economistas sabem: um manual de política econômica para a década de 90 e depois. Tradução de Ruy Jungmann. Rio de Janeiro: Jorge Zahar, 1992.

CARVALHO NETO, Menelick de. Requisitos paradigmáticos da interpretação jurídica sob o paradigma do Estado Democrático de Direito. Revista de Direito Comparado. Belo Horizonte: Faculdade de Direito da UFMG, v. 3, p. 473-486, maio 
1999.

CARVALHOSA, Modesto. Comentários ao código civil: parte especial: do direito de empresa (artigos 1.052 a 1.195). v. 13. Coordenação AZEVEDO Antônio Junqueira de. São Paulo: Saraiva, 2003.

. Comentários à lei das sociedades anônimas. São Paulo: Saraiva, 1977. v.

3.

CASTRO, Manuel Cabral de. Desenvolvimento sustentável: a genealogia de um novo paradigma. In Economia e empresa. São Paulo: Inst. Presbiteriano Mackenzi, v. 3, n. 3, jul./set., 1996.

CATEB, Alexandre Bueno. A sociedade em comum. In Direito de empresa no novo código civil. RODRIGUES Frederico Viana (Coordenador). Rio de Janeiro: Forense, 2004.

CATTONI DE OLIVEIRA, Marcelo Andrade. Direito Constitucional. Belo Horizonte: Mandamentos, 2002.

. Coesão interna entre estado de direito e democracia na teoria discursiva do direito de Jürgen Habermas. In Jurisdição e hermenêutica constitucional no estado democrático de direito. CATTONI DE OLIVEIRA, Marcelo Andrade (coord.). Belo Horizonte: Mandamentos, 2004.

CAVALLI, Cássio. Apontamentos sobre a função social da empresa e o moderno direito privado. In Revista de direito privado. NERY JUNIOR, Nelson; NERY, Rosa Maria de Andrade (coord.). São Paulo: Ed. RT. Ano 6. n. 22, abril/junho, 2005.

Central Única dos Trabalhadores. Esquema das três revoluções do capitalismo. Revista "De Fato", 1993. Disponível em $<$ http://www.cefetsp.br/edu/eso/globalizacao/revolucoes.html>. Acesso 04 mar. 2006. CHAMON JÚNIOR, Lúcio Antônio. Filosofia do direito na alta modernidade. Rio de Janeiro: Lumen Juris. 2005.

Tertium non datur: pretensões de coercibilidade e validade em face de uma teoria da argumentação jurídica no marco de uma compreensão procedimental do Estado Democrático de Direito. In Jurisdição e hermenêutica constitucional no estado democrático de direito. CATTONI DE OLIVEIRA, Marcelo Andrade (coord.). Belo Horizonte: Mandamentos, 2004.

CHIAVENATO, Idalberto. Teoria geral da administração. Volume 1. 6. ed. Rio de Janeiro: Campus, 1999.

. Gestão de pessoas; o novo papel dos recursos humanos nas

organizações. $19^{\mathrm{a}}$ ed. Rio de Janeiro: Campus, 1999.

COELHO, Fábio Ulhoa. Curso de direito comercial, volume 1. 9. ed. ver. e atual. São Paulo: Saraiva, 2005. 
Curso de direito comercial, volume 2. 8. ed. São Paulo: Saraiva, 2005.

. Manual de direito comercial. São Paulo: Saraiva, 1999.

. Parecer do Dr. Fábio Ulhoa sobre sociedade simples. Disponível em

<http://www.irtdpjsaopaulo.com.br/ParecerFabio.htm>. Acesso em 09 jan. 2006.

COSTA, John Dalla. The ethical imperative: why moral leadership is good business. Reading: Addison-Wesley, 1998.

CUNHA, Sandra Baptista; GUERRA, Antonio José Teixeira (org.). A questão ambiental: diferentes abordagens. São Paulo: Bertrand Brasil, 2003.

DIAS, Reinaldo. As empresas e o padrão de qualidade ambiental. In Economia e empresa. São Paulo: Inst. Presbiteriano Mackenzi, v. 2, n. 3, jul./set., 1995.

DRUCKER, Peter Ferdinand. Practice of Management. Nova York: 1954. In Peter Drucker: filosofia e métodos. [por] Tony H. Bonaparte e John E. Flaherty (editores). Tradução de Cláudio Giordano; supervisão editorial de Carlos José Malferrari. São Paulo, Pioneira, 1976.

. Administrando em tempos de grandes mudanças. Tradução Nivaldo Montingelli Jr:; Supervisão técnica LilianaGuazzelli. 3. ed. São Paulo: Pioneira, 1996. Título original: Managing in a time of great change.

FARIA, Edimur Ferreira de. Curso de direito administrativo positivo. Belo Horizonte: Del Rey, 1997.

FARIAS, Edilsom. Democracia, censura e liberdade de expressão e informação na Constituição Federal de 1988. Jus Navigandi, Teresina, a. 5, n. 51, out. 2001. Disponível em: <http://jus2.uol.com.br/doutrina/texto.asp?id=2195>. Acesso em 05 fev. 2006.

FERNANDES, Rubens César. Elos de uma cidadania planetária. Extraído do site $<$ http://www.rits.org.br/idac.rits.org.br/elos/idac_elos_6.html>. Acesso em 09 ago. 2006.

FERREIRA, Antonio Ademir; REIS, Ana Carla Fonseca; PEREIRA, Maria Isabel. Gestão empresarial de Taylor aos nossos dias. Evolução e tendências da moderna administração de empresas. São Paulo: Pioneira, 1997.

FERREIRA, Aurélio Buarque de Holanda. Novo Aurélio XXI:o dicionário da língua portuguesa. 3. ed. totalmente revista e ampliada. Rio de Janeiro: Nova Fronteira, 1999.

FISCHER, Rosa Maria. O desafio da colaboração: práticas de responsabilidade social entre empresas e terceiro setor. São Paulo: Gente, 2002.

FIUZA, Ricardo (coord.). Novo Código Civil comentado. São Paulo: Saraiva, 2002. 
GALBRAITH, John Kenneth. A economia das fraudes inocentes: verdades para o nosso tempo. Tradução de Paulo Anthero Soares Parbosa. São Paulo: Companhia das Letras, 2004.

GRAU, Eros Roberto. A ordem econômica na Constituição de 1988:

interpretação crítica. 9. ed. São Paulo: Malheiros, 2004.

GRAYSON, David, HODGES, Adrian. Compromisso social e gestão empresarial. São Paulo: PubliFolha, 2002.

GRINOVER, Ada Pellegrini, et alii. Código brasileiro de defesa do consumidor comentado pelos autores do anteprojeto. 6. ed. São Paulo: Forense Universitária, 1999.

HABERMAS, Jürgen. A era das transições. Tradução e introdução SIEBENEICHLER, Flávio. Rio de Janeiro: Tempo Brasileiro, 2003.

A inclusão do outro - estudos de teoria política. Tradução SPERBER, George; SOETHE, Paulo A. São Paulo: Loyola, 2002.

HAMILTON, Robert W. The law of corporations - in a nutshell - West Group: St. Paul, Minn., 2000.

HENTZ, Luiz Antonio Soares. A teoria da empresa no novo direito de empresa. Jus Navigandi, Teresina, a. 6, n. 58, ago. 2002. Disponível em:

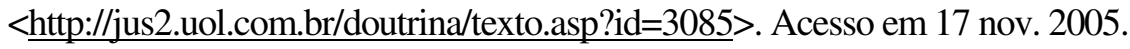

HOUAISS, Antônio . Brasil URSS: 40 anos do estabelecimento de relações diplomáticas. Rio de Janeiro : Revan, 1985.

JOFFILY, Bernardo. Uma revolução que desafia sindicatos. Artigo publicado na revista De Fato, ano 1, número 2. Disponível em $<$ http://www.multirio.rj.gov.br/seculo21/texto_link.asp?cod_link=28\&cod_chave=1 \&letra $=c>$. Acesso em 04 mar. 2006.

KLIKSBERG, Bernardo. Falácias e mitos do desenvolvimento social. Tradução VALENZUELA, Sandra T.; LEITE, Silvana C. São Paulo: Cortez; Brasília, DF: UNESCO, 2001. [Título original: Diez falacias sobre problemas sociales de América Latina.].

KÜNG, Hans. Projeto de ética mundial uma moral ecumênica em vista da sobrevivência humana. Tradução Haroldo Reimer. São Paulo: Paulinas, 1993. Vozes, 1999.

Uma ética global para a política e a economia mundiais. Petrópolis:

LAMY FILHO, Alfredo. A empresa - formação e evolução - responsabilidade social. In Novos estudos de direito comercial em homenagem a Celso Barbi Filho. SANTOS, Theophilo de A. (coord.). Rio de Janeiro: Forense, 2003. 
LELOUCH, Claude. Retratos da vida [filme]. Escrito e dirigido por LELOUCH, Claude. 1981. NTSC/VHS, 168min. Colorido 0006004. RCA. Columbia Pictures International Vídeo. Principais atores: Robert Hossein, Nicole Garcia, Geraldine Chaplin, Jaques Villeret, Fanny Ardant, Evelyne Bouix, Richard Bohringer, JeanClaude Bouttier, Jean-Claude Brialy, Jorge Donn, Ginette Garcin, Francis Huster, Jean-Pierre Kalfon, Macha Meril, Daniel Olbrychski, Raymond Pellegrin, Rita Poelvoorde, Paul Preboist e James Caan. Música de Francis Lai e Michel Legrand. Coreografia (família russa) Maurice Bejart. Co-produção Films 13 - TF1 Films.

LIPPERT, Márcia Mallmann. A empresa no código civil: elemento de unificação no direito privado. São Paulo: Ed. Revista dos Tribunais, 2003.

LIZ, Jorge Pegado. Introdução ao direito e à política do consumo. Lisboa: Notícias, 1999.

LORENZETTI, Ricardo Luis. Consumidores. Buenos Aires: Rubinzal - Culzoni, 2003.

LOURENÇO, Alex Guimarães; SCHRÖDER, Deborah de Souza. Vale investir em responsabilidade social empresarial? Stakeholders, ganhos e perdas. In Responsabilidade social das empresas: a contribuição das universidades. V. II. São Paulo: Peirópolis: Instituto Ethos, 2003.

MACHADO, Sylvio Marcondes. Direito mercantil e atividade negocial no projeto de Código Civil. Questões de direito mercantil. São Paulo: Saraiva, 1977.

Questões de direito mercantil. São Paulo: Saraiva, 1997.

MARQUES, Cláudia L.; BENJAMIN, Antônio H. V.; MIRAGEM, Bruno.

Comentários ao código de defesa do consumidor: aspectos materiais: arts. $1^{\circ}$ a 74. 1. ed. 2. tir. São Paulo: Revista dos Tribunais, 2004.

MARTINS, Fran. Curso de direito comercial: empresa comercial, empresários individuais, microempresas, sociedades comerciais, fundos de comércio. 23. ed. revista e atualizada por Jorge Lobo. Rio de Janeiro: Forense, 1999.

MAXIMIANO, Antonio César Amaru. Teoria geral da administração: da revolução urbana à revolução digital. 5.ed. São Paulo: Atlas, 2005.

MCINTOSH, Malcolm, et alii.; Cidadania corporativa: estratégias bem-sucedidas para empresas responsáveis. Tradução de Bazán Tecnologia e Lingüística. Rio de Janeiro: Qualitymark ed., 2001.

MEIRELLES, Hely Lopes. Direito administrativo brasileiro. 10. ed. atualizada. São Paulo: Ed. Revista dos Tribunais, 1984.

MENEGAT, Marildo. Brasil, do genocídio à barbárie. Entrevista concedida à Agência de Notícias do Planalto. Extraído do site

$<$ http://www.noticiario.com.br/noticias.asp?cod_noticia=4447>. Acesso em 17 jun. 2006. 
MÉSZÁROS, István. Para além do capital - rumo a uma teoria da transição. Tradução CASTANHEIRA, Paulo César; LESSA, Sérgio. São Paulo: Boitempo Editorial, 2002. [Título original: Beyond Capital - Towards a Theory of Transition. Merlin Press, Londres, 1995.]

MOKHIBER, Russell. Crimes corporativos. Tradução de James F. S. Cook. São Paulo: Página Aberta, 1995.

MONTESQUIEU, Charles-Louis de Secondat, Barão de La Brède et de. Do espírito das leis. Tradução: Gabriela de Andrada Dias Barbosa. Introdução: Otto Maria Carpeaux, com anotações de Voltaire, de Crévier, de Mably, de La Harpe, etc. Rio de Janeiro: Tecnoprint, 1968. Edições de Ouro. Título original francês: De L'Esprit dês lois. Direitos cedidos por Edições e Publicações Brasil Editora S.A.

MOORE, Barrington Jr. Aspectos morais do crescimento econômico e outros ensaios. Tradução ALTMAN, Max. Rio de Janeiro: Record, 1999 [Título original norte-americano: Moral aspects of economics growth and other essays. Cornell University Press, 1998.].

MOREIRA, Glória Maria de Pádua. Por uma ecologia social: uma aproximação da noção de desenvolvimento aos princípios éticos do desenvolvimento humano durável. Tese de doutorado apresentada ao Programa EICOS (Estudos Interdisciplinares de Comunidades e Ecologia Social), do Instituto de Psicologia da Universidade Federal do Rio de Janeiro. Rio de Janeiro. 2004.

MORIN, Edgar. Estamos no titanic. Extraído do site $<$ http://www.iadb.org/etica/documentos/Blt_5junio2006-P.htm $>$. Acesso em 12 jun. 2006.

NEVES, Rubia Carneiro. Regime jurídico da sociedade simples. In RODRIGUES, Frederico Viana (Coord.). Direito de empresa no novo código civil. Rio de Janeiro: Forense, 2004.

NOBRE, Suzana Laniado C. Terceiro setor: os recursos da solidariedade. Rio de Janeiro: Qualitymark, 2004.

PELLEGRINI, Flaviane de Magalhães Barros. O paradigma do estado democrático de direito e as teorias do processo. In virtualjus revista eletrônica. Ano 3. julho, 2004.

PIMENTA, Eduardo Goulart. Exclusão e retirada de sócios: conflitos societários e apuração de haveres no Código Civil e na Lei das Sociedades Anônimas. Belo Horizonte: Mandamentos, 2004.

. Direito, economia e relações patrimoniais privadas. In Revista de informação legislativa. Brasília. Ano 43. n. 170. abril/junho, 2006.

Teoria da empresa em direito e economia. In Revista de direito público da economia - RDPE, Belo Horizonte, ano 4, n. 14, p. 55-74, abr.jun., 2006. 
PINHEIRO, Armando Castelar, SADDI, Jairo. Direito, economia e mercados. Rio de Janeiro: Elsevier, 2005.

PINHO, Afonso Júlio. O contexto histórico do nascimento das relações públicas. Disponível em <http://www.jornalismo.ufsc.br/redealcar/cd3/rp/juliopinho.doc>. Acesso 04 mar. 2006.

REQUIÃO, Rubens. Curso de direito comercial. vol. 1. 25. ed. atualizada por Rubens Edmundo Requião. São Paulo: Saraiva, 2003.

ROCHA FILHO, José Maria. Curso de direito comercial. 3. ed. revisada, atualizada e ampliada. Belo Horizonte: Del Rey, 2004.

ROSE, Ricardo. Legislação e normas ambientais na América Latina. Extraído do site <http://www.reciclagem.net>. Acesso em 31 jul. 2006.

SANTOS, Boaventura de Sousa. O fórum social mundial: manual de uso. São Paulo: Cortez, 2005.

SARMIENTO, Suzana. Evento em Curitiba apresenta experiências bem sucedidas em Responsabilidade Social. Disponível em $<$ http://www.setor3.com.br/senac2>. Acesso em 11 out. 2005.

SÉLLOS, Viviane Coelho de. Responsabilidade do profissional liberal pelo fato do serviço no código de proteção e defesa do consumidor. In Revista Direito do Consumidor, $n^{\circ}$ 10. São Paulo: Ed. Revista dos Tribunais, 1994.

SIQUEIRA, Graciano Pinheiro de. O direito de empresa e o novo Código Civil. Disponível em <http://www.irtdpjsaopaulo.com.br/DireitodeEmpresa.htm>. Acesso em 10 jan. 2006.

SMITH, Denis. As empresas e o ambiente: implicações do novo ambientalismo. Tradução de Paula Mendes. Lisboa: Instituto Piaget, 1993.

SROUR, Robert Henry. Ética empresarial: a gestão da reputação. 5. reimpressão. Rio de Janeiro: Elsevier, 2003.

SZTAJN, Rachel. Teoria jurídica da empresa: atividade empresária e mercados. São Paulo: Atlas, 2004.

TEIZEN JÚNIOR, Augusto Geraldo. A função social no código civil. São Paulo: Ed. Revista dos Tribunais, 2004.

TOMAZETTE, Marlon. As sociedades simples no novo código civil. Disponível em <http://jus2.uol.com.br/doutrina/texto.asp?id=3691\&p=2>. Acesso em 06 nov. 2005.

TRINDADE, Antônio Augusto Cançado. Direitos humanos e meio-ambiente: paralelo dos sistemas de proteção internacional. Porto Alegre: Sergio Antonio Fabris Editor, 1993.

VALLS, Álvaro L.M. O que é ética. 9. ed. São Paulo: Brasiliense, 1994. 
VAZ, Isabel. Direito econômico das propriedades. 2. ed. Rio de Janeiro: Forense, 1993.

VELOSO, Letícia Helena Medeiros. Responsabilidade social empresarial: a fundamentação na ética e na explicitação de princípios e valores. In Ética e responsabilidade social nos negócios. ASHLEY, Patrícia Almeida (Coordenadora). 2. ed. São Paulo: Saraiva, 2006.

WALD, Arnoldo. Novas perspectivas para a empresa. In Revista Síntese de Direito Civil e Processual Civil. v.10, mar./abr., 2002.

ZACHARIAS, Oceano. SA 8000 - Responsabilidade social - NBR 16000: estratégia para empresas socialmente responsáveis. São Paulo: Editora EPSE, 2004.

ZAVALA, Rodrigo. Mais empresas têm ação social, mas volume de recursos cai. Dados disponíveis no site <http://www.gife.org.br/>.Acesso em 06 ago. 2006.

Recebido em 27-09-2011

Avaliado em 14-11-2011

Aprovado para publicação em 05-12-2011 